ROBERT Z. LA WRENCE

Harvard University

MAT THEW J. SLA UGHTER

Massachusetts Institute of Technology

\title{
International Trade and American Wages in the 1980s: Giant Sucking Sound or Small Hiccup?
}

THE AMERICAN DREAM IS THAT each generation should live twice as well as its predecessor. During the hundred years before 1973, real average hourly earnings rose by 1.9 percent a year. ${ }^{1}$ At that rate earnings doubled every thirty-six years, and the dream was realized.

The dream no longer holds. Since 1973 the United States has failed to match its historic track record. In 1973 average real hourly earnings, measured in 1982 dollars by the consumer price index (CPI), were $\$ 8.55$. By 1992 they had actually declined to \$7.43-a level that had been achieved in the late 1960s. Had earnings increased at their pre-1973 pace, they would have risen by 40 percent to more than $\$ 12.00$. Or consider average real hourly compensation. This is a more comprehensive measure of the payments to labor because it includes fringe benefits as well as earnings. Between 1973 and 1991, real hourly compensation rose by only 5 percent. However the growth of labor income is measured, it clearly has slumped since 1973.

A second ominous development in the American economy has accompanied this slump: a dramatic increase in the inequality of earnings. In

This paper reflects research on a Brookings Institution project, "First Among Equals," funded by the Ford Foundation. We are grateful to Martin Neil Baily, Lawrence Katz, Edward Leamer, and John Pencavel and participants at the Brookings Panel and the National Bureau of Economic Research Summer Institute for comments, Lael Brainard and Paul Krugman for helpful discussions, Scott Bradford for research assistance, and Wayne Gray for data.

1. See Johnson and Stafford (1993, p. 1). 
particular, the earnings of skilled workers have risen sharply relative to those of their less qualified counterparts. Bound and Johnson have calculated this divergence based on education. They found that between 1979 and 1988, the ratio of the average wage of a college graduate to the average wage of a high school graduate rose by 15 percent. ${ }^{2}$ Steven Davis has calculated this divergence in terms of work experience. ${ }^{3} \mathrm{He}$ found that between 1979 and 1987, the ratio of weekly earnings of males in their forties to weekly earnings of males in their twenties rose by 25 percent. The Employment Cost Index (ECI) tells a similar story. Assembled by the Bureau of Labor Statistics (BLS), the ECI classifies workers by occupation, and it indicates that between December 1979 and December 1992, the growth of compensation and earnings of white-collar occupations exceeded those of blue-collar occupations by 7.9 and 10.9 percent, respectively. However the skilled are distinguished from the unskilled, the sharp rise in wage inequality between the two in the 1980s is clear. (See the appendix for a brief discussion on making this distinction).

These two developments - sluggish and unequal real wage growthhave coincided with three major changes in the nation's international economic relations.

The first is convergence: the change in the United States' comparative position from global economic preeminence to "first among equals." In the 1950s output per worker in the United States was twice that in Europe and six times that in Japan. Today, both Europe and Japan have closed most of the output gap. ${ }^{4}$ In addition, since the 1950s foreign stocks of both human and physical capital have been growing more rapidly than in the United States. The result has been a convergence in wage rates. In 1975 a trade-weighted average of foreign compensation rates expressed in U.S. dollars was equal to 64 percent of U.S. levels. By 1980 this measure stood at 72 percent, and by 1990 at 93 percent. $^{5}$

2. Bound and Johnson (1992). The education differential has risen most sharply among inexperienced workers. Murphy (1992) found that in 1979 the hourly wage of a college graduate with fewer than five years of work experience was 30 percent more than that of a high school graduate with similar experience. In 1989 this premium had soared to 74 percent.

3. Davis (1992).

4. McKinsey Global Institute (1992).

5. This measure includes twenty-four U.S. trading partners; it excludes Brazil, Mexico, and Israel. When these countries are included, the 1990 trade-weighted foreign manufacturing compensation measure equals 88 percent of America's. Data come from the Bureau of Labor Statistics (1991). 
The second major change is globalization: the increased volumes of foreign trade and foreign direct investment in America. Between 1970 and 1990 U.S. exports and imports rose from 12.7 percent of gross national product (GNP) to 24.9 percent. During the 1980s the ratio of the stock of inward foreign direct investment to GNP, valued on a historic cost basis, grew from 3 percent to 8.1 percent. Since the first oil shock in 1973, Americans have been forced to adjust to foreigners as suppliers of raw materials, as competitors in manufactures (such as automobiles), and, finally, as bankers and bosses.

The third major change is spending: the shift in American spending patterns in the 1980s, which produced record trade deficits. The Reagan administration's combination of expansionary fiscal policy and contractionary monetary policy helped cause an unprecedented appreciation of the U.S. dollar until 1985. This record strength of the dollar priced many American exporters out of the world market, and it made imports a bargain for American consumers. The result was record trade deficits, which increased from 0.5 percent of gross domestic product (GDP) in 1980 to nearly 3.5 percent of GDP in 1987.

Because the United States' changed international economic relations coincided with the slow and uneven wage growth, it is scarcely surprising that the former has frequently been advanced as a primary cause of the latter. This connection is often made in policy discussions-recall Ross Perot, for example. In the 1992 presidential debates he claimed that ratification of the North American Free Trade Agreement would generate "a giant sucking sound," with high wages and challenging jobs fleeing to Mexico. This claim struck a nerve with millions, and helped him win 19 percent of the popular vote.

Many academics have also linked international factors to wage developments. For example, Johnson and Stafford argue that the erosion of high returns from American technological leadership has been the principal source of the slow rise in American real wages since 1973. Similarly, Leamer claims that increased capital formation abroad is leading inevitably to "factor price equalization," in which American wage rates converge with those in other countries. According to Leamer this convergence is harmful because it entails not simply a rise in foreign wage levels, but also a decline in American wage levels. Reich argues that global competition has bifurcated American workers - and thereby American societyinto two groups: high-earning "symbolic analysts" whose talents are 
rewarded by globalization, and the mass of ordinary production workers whose earnings are depressed by it. Referring to growing wage disparity, Murphy and Welch conclude that "the evolving pattern of international trade is perhaps a primary cause of recent wage changes." 6

Other academics, however, have argued that international factors have played only a small role in recent wage changes. Borjas, Freeman, and Katz maintain that trade flows explain, at most, 15 percent (that is, 1.9 percentage points) of the 12.4 percent increase between 1980 and 1988 in the earnings differential between college-educated workers and their highschool-educated counterparts. Moreover, because the manufacturing trade deficit declined from $\$ 106$ billion in 1988 to $\$ 47$ billion in 1991 , their method would attribute to trade less than one percentage point of the disparity in relative wage growth that persists today. Davis finds that increased trade is associated with a convergence across several countries of relative-wage structures. But he concludes that this factor-price equalization effect has been more than offset by the growing divergence across countries of relative industry wage structures. Freeman and Needels find that the college-high school wage differential increased only slightly in Canada during the 1980 s. They conclude from this that the wage divergence in the United States was not the result of "an inexorable shift in the economic structure of advanced capitalist countries," but a reflection of "specific developments in the U.S. labor market." Berman, Bound, and Griliches do not find much role for trade, and Bound and Johnson find that trade played basically no role in America's wage changes in the 1980s. Instead, they ascribe these changes to technological change and changes in unmeasured labor quality. ${ }^{7}$

The effect of America's international economic relations on both its real and relative wages is thus a controversial topic. It also consumes an increasing part of the policy debate. Although trade intervention is rarely the ideal instrument for redistributing income, it is often a tempting one. Leamer, for example, argues that liberalizing trade with developing countries such as Mexico costs the United States an important mechanism for maintaining the wages of its least fortunate workers.

In this paper we try to advance the debate by presenting a data analysis

6. Johnson and Stafford (1993); Leamer (1992); Reich (1991); and Murphy and Welch (1991).

7. Borjas, Freeman, and Katz (1992); Davis (1992); Freeman and Needels (1991); Berman, Bound, and Griliches (1993); and Bound and Johnson (1992). 
that uses insights from theory to investigate the effect of international trade on America's recent wage performance. We first look at the sluggish growth of average real wages. As a first approximation we expect the performance of average real wages to mirror the performance of output per worker. Accordingly, we explore reasons for the divergence between real wages and labor productivity. Our main finding is that trade had nothing to do with the slow increase in average compensation. The sluggish rise in real compensation and the accompanying convergence of U.S. and foreign wages reflected slow productivity in the nontraded goods sectors of the American economy. Real product compensation increased almost as rapidly as output per worker. Growth of real consumption compensation lagged behind real product compensation because of a rise in the relative price of housing (which workers consume but do not produce) and a decline in the relative price of investment goods (which workers produce but do not consume).

We next consider the rise in the relative wages of nonproduction workers. Standard international trade theory, as laid out by Stolper and Samuelson, suggests that changes in the relative returns of factors will reflect changes in the prices of the goods that they produce. ${ }^{8}$ Many studies of relative wage performance have ignored this process, however. ${ }^{9}$ Instead, they focus on trade volumes and trade deficits. As Bhagwati has emphasized, trade deficits are not the most suitable measures of the effects of trade because they are not necessarily associated with relative wage behavior. ${ }^{10}$ We focus instead on the price behavior of traded goods, and we find no evidence that the relative prices of goods that use production labor relatively intensively have declined. From this evidence, we conclude that relative U.S. wages have not been driven by Stolper-Samuelson effects. We do, however, find a positive association between the growth of total factor productivity and the intensive use of nonproduction labor. This points to technological change as an important source of changes in relative wages. Indeed, we argue that the pervasive decline in the ratio of production to nonproduction workers actually employed-despite the decline in the relative wages of production workers-points to a dominant role for technological change, which has augmented employment of non-

8. Stolper and Samuelson (1941).

9. Leamer (1992) is a noteworthy exception, but see footnote 39 .

10. Bhagwati (1991). 
production workers. This accords well with anecdotal evidence of the shift toward computer-controlled, flexible manufacturing systems.

We then consider and reject two more complex hypotheses about the effect of trade on wages. We analyze models that assume complete specialization and the hypothesis that trade has eroded union rents. We conclude with a summary of our major findings and some observations on the important role played by the productivity slowdown outside of manufacturing.

\section{Average Wages}

What has happened to real average wages of U.S. workers? To answer this question, one must first define "wages." One source of confusion reflects the inconsistent use of conceptually distinct data series. The most commonly cited statistic, average real hourly earnings of production workers, shows a decline of almost 11 percent between 1979 and 1991. By contrast, a second commonly cited series, average real hourly compensation in the business sector, shows an increase of 1.5 percent during the same period. These series differ in two ways. First, the average hourly earnings series samples only production and nonsupervisory workers, while the hourly compensation series includes all persons engaged in work (including the self-employed). Second, the hourly earnings series reflects only wages, while the compensation measure includes employers' contributions for social insurance and private benefit plans (including retirement and medical care). Both differences are important, and the series have diverged for two reasons. First, the wages of production workers have risen more slowly than those of nonproduction workers. Second, fringe benefits for all workers have increased more rapidly than wages.

The ECI offers an indication of the relative roles of these two factors in earnings behavior. It suggests that half of the shortfall between the average hourly series and average compensation reflects the relatively slower increase in the earnings of production workers, and the other half the relatively rapid rise in the costs of employer-provided taxes and fringe benefits (especially medical care). Indeed, between December 1979 and December 1991, the ratio of average earnings of bluecollar workers to average earnings in the private sector declined by 5.7 
percent, and the ratio of average compensation to average earnings in the private sector increased by 5.7 percent.

From a theoretical standpoint compensation, rather than earnings, is the relevant measure of wages. We expect workers to be hired as long as their compensation cost is less than their marginal revenue product. In equilibrium, therefore, we expect nominal compensation at time $t$, $w_{t}$, to equal labor's marginal revenue product at time $t, m r p_{t}$ :

$$
w_{t}=\operatorname{mrp}_{t}=P_{t} \times m p p_{t} .
$$

Note that $m r p_{t}$ is defined, as usual, as the product price at time $t, P_{t}$, and the marginal physical product of labor at time $t, m p p_{t}$.

Expressing equation 1 in logarithms and differentiating it with respect to time produces

$$
w_{t}^{*}=P_{t}^{*}+m p p_{t}^{*} .
$$

Here, $w_{t}^{*}$ denotes $\operatorname{dlog}\left(w_{t}\right) / d t$, etc. Changes in compensation are the sum of changes in both product prices and the marginal physical product of labor.

In the long run in a conventional neoclassical growth model, we also expect changes in the marginal physical product of labor to match changes in the average physical product (app) of labor, which equals output per worker. Thus $m p p_{t}^{*}=a p p_{t}^{*}$, and we can write

$$
w_{t}^{*}=P_{t}^{*}+a p p_{t}^{*} .
$$

This suggests that as a first approximation, we expect changes in real compensation to match the change in output per worker:

$$
w_{t}^{*}-P_{t}^{*}=a p p_{t}^{*} .
$$

Now consider what happened in the United States.

\section{The Output-Wage Gap}

We focus on the period since 1979 , because 1979 is when slow average wage growth and rising relative wage dispersion-the two phenomena we are interested in-became apparent. The growth of output per worker in the United States slowed dramatically after 1973. But, as figure 1 illustrates, between 1973 and 1979 average real compensation increased in line with output per hour in the U.S. business 


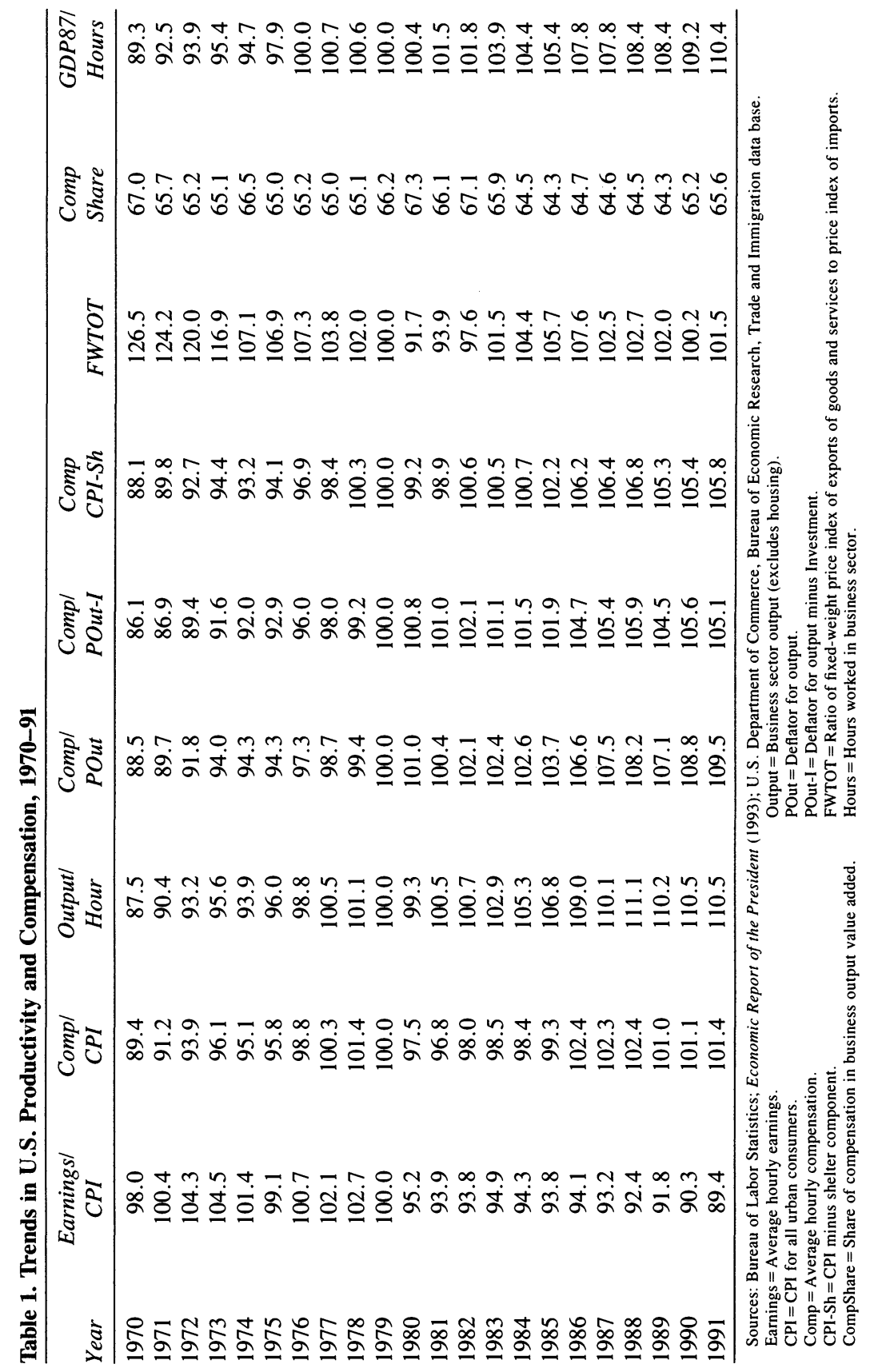


sector. From 1979 to 1991 output per worker grew by 10.5 percent-a very slow pace by historical standards. During the same period, however, real compensation (average hourly compensation deflated by the $\mathrm{CPI}-\mathrm{U}$, the consumer price index for urban consumers) grew by only 1.5 percent. Apparently, the growth of real compensation failed to match the slow growth in output per worker. Here, then, is the outputwage gap that needs explaining.

If workers have not seen their real incomes rise as rapidly as output per worker, it is quite natural to assume that someone else has received this difference. One candidate is owners of capital, and a second is foreigners. Indeed, both the decade of greed and the effect of international convergence both in reducing U.S. buying power and in shifting income away from labor have been cited as explanations of the outputwage gap. ${ }^{11}$

These explanations can be rejected in favor of a more straightforward one that involves the basket of goods to which $P_{t}$ refers. The $P_{t}$ used in equation 4 measures a basket of goods produced in the United States. The CPI used in calculating real compensation, however, measures a basket of goods typically consumed in the United States. The key point is that the two baskets do not contain the same goods. It follows that nominal compensation deflated by the CPI does not equal nominal compensation deflated by a basket of production goods. Indeed, if nominal compensation is deflated by the output deflator used in the businessoutput measures of productivity, we find that between 1979 and 1991 real product compensation actually increased by 9.5 percent-just one percentage point less than the increase in output per worker (table 1). Thus if the appropriate $P_{t}$ is used to measure $\left(w_{t}^{*}-P_{t}^{*}\right)$, equation 4 basically does describe the United States from 1979 to 1991 . By deflating wages with the appropriate prices, the output-wage gap disappears.

This means that the income of the business sector has not shifted away from wages and toward profits. ${ }^{12}$ Indeed, in 1991 the share of

11. See Krugman (1992) on the decade of greed. See, for example, Johnson and Stafford (1993) on buying power; Leamer (1992) on the income shift.

12. Define $S$ as labor's share in income, where $W$ is the nominal compensation rate, $L$ employment, $P$ the price of output, and $Q$ the quantity of output: $S=W L / P Q$. Expressing both sides in logs, taking the derivative with respect to time, and rearranging, we get $S^{*}=W^{*}-P^{*}-\left(Q^{*}-L^{*}\right)$. Here, $S^{*}=\mathrm{dLog} S / \mathrm{d} t$, etc. So changes in labor's 
total compensation in the value added by the business sector was 65.6 percent, less than one percentage point lower than it was in 1979 (see table 1). The share of compensation tends to rise during slumps and fall during recoveries, and the share in 1991 was higher than in the late 1970 s and was close to its 1970-90 average. What explains the differences between these output data and the more publicized versions based on household and personal income, which indicate growing inequality? As Cutler and Katz convincingly demonstrated, the discrepancies arise because of data definitions. ${ }^{13}$ Unlike data on personal income, data on national income accounts include in the return to capital both reinvested earnings and taxes on corporate earnings and exclude capital gains and interest paid on the government debt. The divergence between the output and income measures can be ascribed to these differences. Profits, therefore, did not increase dramatically at the expense of compensation.

Our explanation of the output-wage gap also means that trade developments did not shift income away from labor. We will describe, in the context of a two-factor model, how the traditional Stolper-Samuelson model predicts that changes in the terms of trade reduce the real product return of the factor used intensively in the production of the good whose relative price falls. The finding that real product wages have matched productivity growth is an important piece of evidence that contradicts those who use such a model to argue that the poor performance of average wages in the United States reflects trade's raising the return to capital and lowering the return to labor. If trade had done this, the real product wage would have declined. Instead, it actually rose by as much as productivity, which means that trade did not have the impact just described.

Indeed, the behavior of the aggregate U.S. business sector between 1979 and 1989 matches the predictions of a conventional neoclassical growth model with pure labor-augmenting technical change. We have already noted that factor shares were constant and that real product compensation rose at the rate of growth of output per worker. We should add that the capital-output ratio remained fairly constant. The growth rates of the net capital stock of fixed nonresidential capital and business

share are equal to the difference between changes in the product wage, $\left(W^{*}-P^{*}\right)$, and changes in output per worker, $\left(Q^{*}-L^{*}\right)$.

13. Cutler and Katz (1991). 
Figure 1. Output per Hour and Real Hourly Compensation, 1979-90

$1973=100$

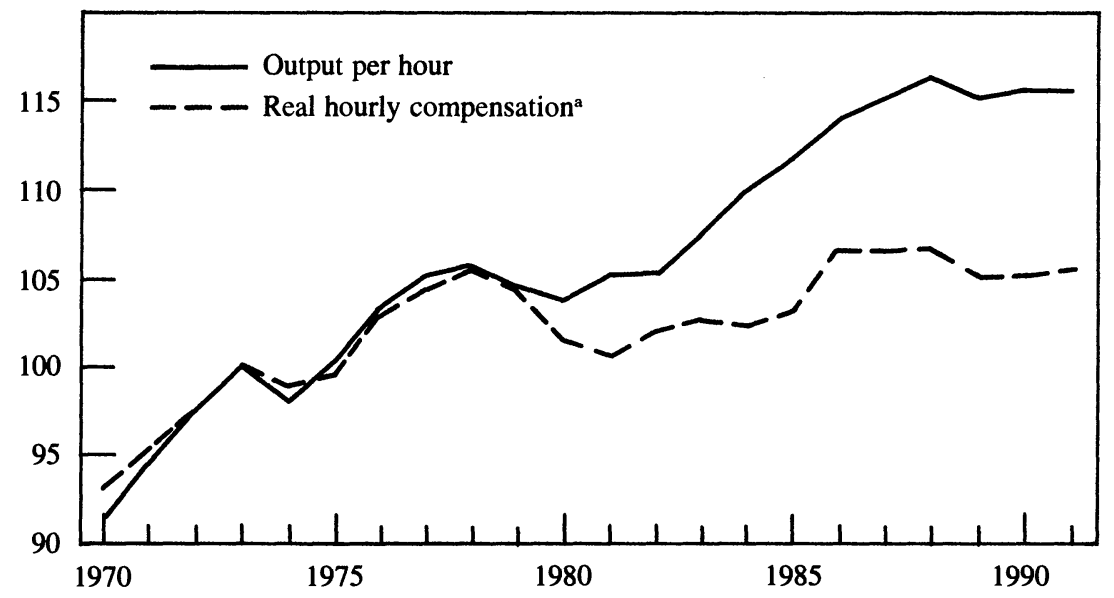

Source: Council of Economic Advisers, Economic Report of the President 1993, table B42, p. 396; table B44, p. 398.

sector output were 31.5 percent and 29.6 percent, respectively. ${ }^{14}$ As a result the 1989 ratio of business sector profits to net capital stock of 9.1 percent was similar to the 1979 ratio of 8.7 percent.

To summarize, we find that if nominal compensation is deflated by production prices rather than consumption prices, workers in the $1980 \mathrm{~s}$ were basically compensated for their growth in output per worker. If workers had chosen to consume the products they actually produced, they would have raised their real compensation by as much as the improvement in productivity growth. The wage gap illustrated in figure 1 is thus almost totally due to a discrepancy between the production and the consumption wage. Apparently, the prices of the products that workers consume have risen more rapidly than those that they produce.

\section{Production versus Consumption Compensation}

Three major differences in the composition of the deflators for production and consumption compensation merit attention.

First come investment goods. The CPI does not, of course, reflect

14. Capital-stock data are from the January 1992 Survey of Current Business. Business-sector output data are from Council of Economic Advisers, 1993 Economic Report of the President, Washington, D.C.: GPO, p. 398. 
the prices of investment goods. The prices of the most rapidly growing investment goods, computers, have declined precipitously, and hedonic price series indicate that productivity growth in the computer sector has been particularly rapid. Simply subtracting gross domestic investment from business-sector output provides a measure of consumption goods output. ${ }^{15}$ The implicit deflator from this series suggests that between 1979 and 1991 real compensation in terms of consumer goods increased by 5.1 percent (versus 1.5 percent using the CPI-U). Thus, about half of the shortfall between consumption compensation and production compensation can be explained by the relative price decline of investment goods.

A second major compositional difference between consumption and production prices is housing. Output of owner-occupied housing is not included in the business-sector price measure put out by the BLS. The cost of owner-occupied housing, however, constitutes 20 percent of the CPI, and this cost has been inflating particularly rapidly: between 1979 and 1991, the index of shelter prices increased 17 percent more rapidly than did the rest of the CPI. If hourly compensation is deflated by the CPI minus shelter, then real compensation between 1979 and 1991 increased by 5.8 percent. This estimate is roughly equal to the previous estimate that was calculated using the business deflator minus investment goods. ${ }^{16}$

The third major difference between production and consumption prices involves international trade. Imported goods make up part of the consumption basket, but not the production basket. There is a widespread view that foreign economic growth necessarily increases aggregate U.S. welfare because it provides increased opportunities for trade. ${ }^{17}$ As Hicks pointed out long ago, however, this is not necessarily correct. ${ }^{18}$ Given domestic output, national welfare depends on the terms

15. This measure is crude because investment includes expenditures on imported capital goods.

16. It should be noted that for workers who own their own homes, the deflation of real earnings by the CPI-U provides an unduly pessimistic view of income growth because it neglects the "real" increase in their incomes earned from home ownership. The fact that housing output (including that imputed to owner-occupied housing) is a component of gross domestic product (GDP) helps explain why GDP per hour has also increased faster than real compensation.

17. See, for example, Williamson (1991).

18. Hicks (1953). 
of trade-the ratio of export to import prices. Foreign growth will raise aggregate U.S. welfare if it improves the nation's terms of trade by providing either larger markets for U.S. products or cheaper imports, or both. If growth induces foreigners to boost output of U.S. exportables (or to shift out of U.S. importables), U.S. welfare could be reduced. ${ }^{19}$ In principle, therefore, the sluggish increase in average U.S. real wages could reflect a decline in U.S. terms of trade. Johnson and Stafford have formalized this argument. ${ }^{20}$

Given domestic output, real compensation rises when workers must give up fewer resources to obtain a given quantity of imports. Whether real compensation actually rises in this way depends on two factors. The first is the productivity with which factors can be combined to produce domestic products, and the second is the rate at which domestic products can be exchanged for imports - that is, the terms of trade. If increases in product wages match growth in domestic productivity (as our work says they have), then the level of real compensation depends on the nation's terms of trade.

In figure 2, we depict a fixed-weight measure of the terms of trade over the period of interest. This series actually indicates a small improvement of 1.5 percent in the terms of trade. (Indeed, the broadest measure, which uses GDP deflators for all tradables, shows an increase of 5.2 percent.). ${ }^{21}$ Other things equal, these slightly improved terms of trade meant slightly higher real compensation.

The Command GNP, put out by the Central Intelligence Agency (CIA), also shows that the terms of trade actually raised real compensation. Designed to capture the effect of the United States' changed international buying power, Command GNP differs from conventional GNP in that it deflates nominal exports by the import deflator rather than the export deflator. If the terms of trade worsen, Command GNP falls relative to GNP - as does U.S. international buying power. Figure 3 shows that during the 1980 s Command GNP actually rose 2 percent more than GNP did. This means that U.S. buying power grew slightly

19. It should be stressed that simply because the gains from trade have been reduced, it does not follow that protection would be a superior policy.

20. Johnson and Stafford (1993).

21. As shown in Lawrence (1990), excluding the prices of computers, oil, and agriculture indicates that virtually no change occurred in the terms of trade for other goods and services between 1980 and 1990. 
Figure 2. Current Account, Terms of Trade, and Real Exchange Rates, 1979-90

Percent of GNP

$1979=100$

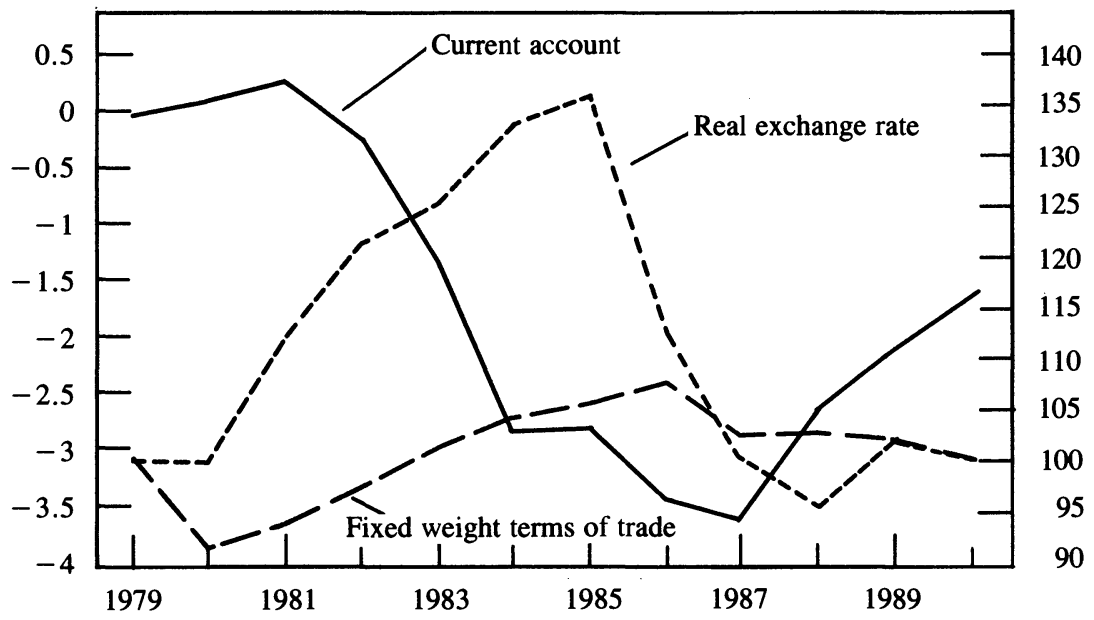

Source: Current account data from Council of Economic Advisers, Economic Report of the President 1993, table B100, p. 462; terms of trade data from authors' calculations, based on U.S. Department of Commerce, Survey of Current Business, various issues; exchange rate data from Morgan Guaranty Trust Co., World Financial Markets, various issues.

Figure 3. Ratio of Command GNP to GNP, 1959-91

1987 dollars

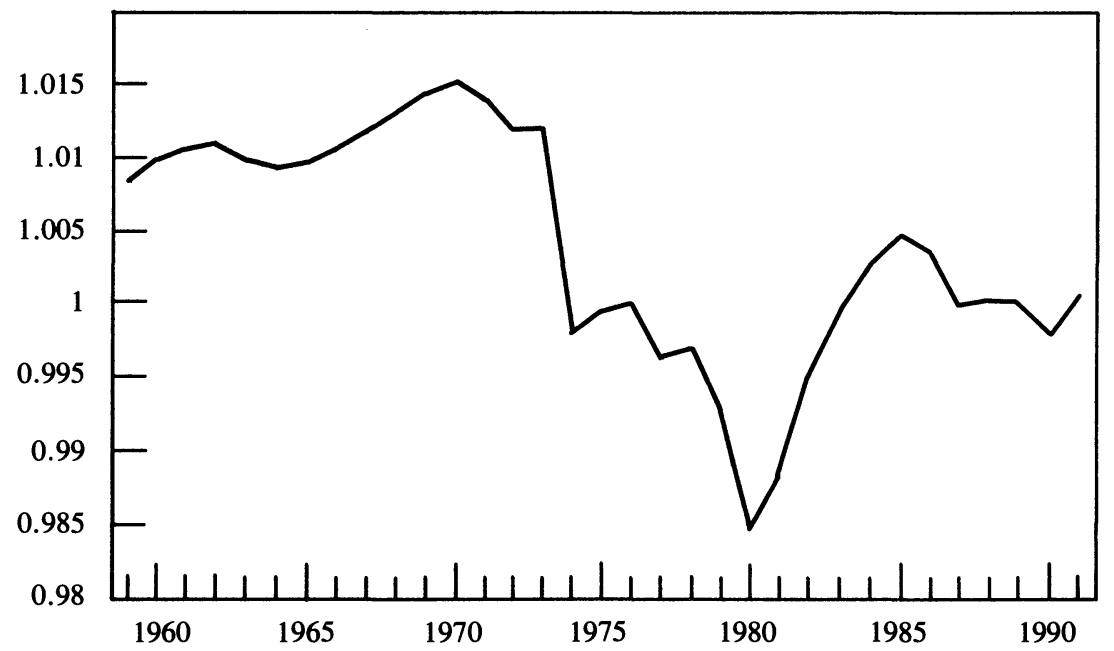

Source: CIA. 
in the 1980s. Therefore, both fixed-weight terms of trade and Command GNP indicated that trade-via the terms of trade-has actually been a slightly positive factor in the performance of real compensation.

Of course, the terms of trade did fluctuate in the 1980s. A nation's terms of trade can shift for two very different reasons. They can shift because of competitiveness, that is, if consumers at home or abroad change the quantities they would like to buy at given prices. They can also shift because of changes in total spending. Domestic spending tends to fall more heavily on domestic products than foreign spending does. Accordingly, when domestic spending rises relative to foreign spending, rising terms of trade are expected (in addition to a deteriorating current account balance). To evaluate the effect of competitiveness on terms of trade, therefore, we must control for the effect of total spending.

Consider the behavior of the U.S. terms of trade in the 1980s. Notice in figure 2 how the emergence of the current account deficit in the first half of the 1980s was associated with both an improvement in the terms of trade and an appreciation of the real exchange rate. Also notice how both the terms of trade and the real exchange rate peaked in 1985 and then moved back to roughly their 1980 levels by 1988. The current account deficit, however, persisted. So the improvement in the terms of trade was associated with a deterioration in the current account. This association implies that the improvement in the terms of trade was not caused by improved U.S. competitiveness, but instead reflected a surge in U.S. spending relative to production. ${ }^{22}$

Although the real exchange rate and the terms of trade had nearly returned to their 1980 levels by 1990 , the current account still has not. American workers, therefore, have not yet paid the price in terms of the loss of trade required to restore the trade balance in goods and services to its 1980 level. If historical relationships prevail, in addition to the required reductions in U.S. spending relative to income, a real decline in the dollar on the order of about 10 percent will be required to restore the trade balance to its 1980 s levels. ${ }^{23}$ Because imports ac-

22. One mechanism by which the U.S. terms of trade were shifted was changes in the real exchange rate. If firms selling traded goods kept their price fixed in terms of domestic currencies, the terms of trade and the real exchange rate would be expected to move together.

23. Lawrence (1990). 
Figure 4. Output per Hour by Selected Sectors, 1979-91

1987 dollars

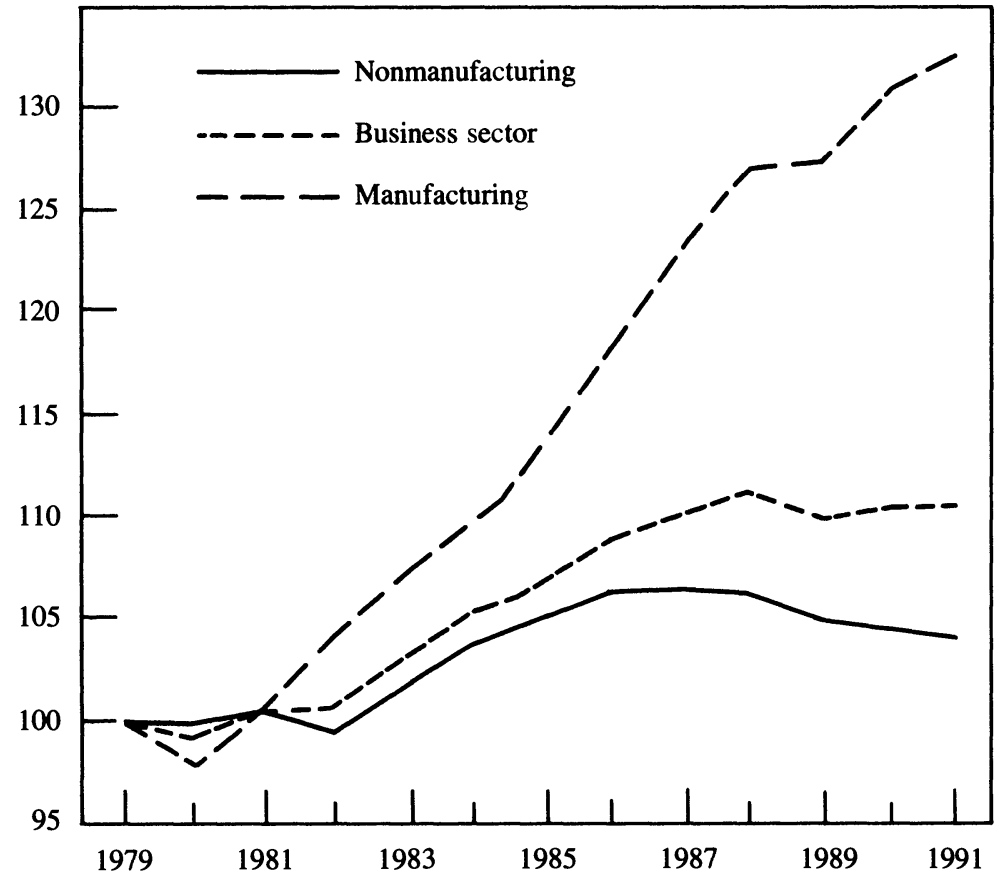

Source: Bureau of Labor Statistics, 1992, International Comparisons of Hourly Compensation, Costs for Production Workers in Manufacturing, 1976-91, Report 825, GPO.

1979 equals 100.

count for about 13 percent of U.S. spending, the effect of this change on living standards would probably be just above 1 percent.

\section{Productivity Growth}

We said that output per worker since 1979 has grown more slowly than it did in previous decades. To analyze this slowdown, we divided the growth in business-sector output per hour into two components: manufacturing and nonmanufacturing. Figure 4 displays this breakdown. Here, manufacturing output is measured in 1987 dollars, which tends to bias downward productivity growth before 1987 because of the treatment of computer-price weights. Despite this bias it is striking that in the 1980s manufacturing actually performed near its historic norms. 
Between 1979 and 1990 output per hour in manufacturing grew 30.7 percent, measured in 1987 dollars. During the same period nonmanufacturing output per hour grew by only 4.5 percent. This weak performance in nonmanufacturing productivity is the primary cause of the slump in aggregate productivity growth-and therefore in real wage growth as well. ${ }^{24}$

Some believe that these data reflect considerable mismeasurement. ${ }^{25}$ It is noteworthy, however, that before 1973 productivity growth in the nonmanufacturing portion of the business sector was only slightly slower than that recorded in the manufacturing portion. No historical evidence, therefore, indicates that productivity growth is inevitably slower outside of manufacturing. Moreover, before 1973 measurement problems did not prevent the detection of significant productivity increases outside of manufacturing. To attribute the entire slowdown in services productivity to measurement problems, it is necessary to argue not only that productivity in services is difficult to measure, but also that this measurement has recently grown more difficult to make.

Some have argued that trade has kept the U.S. manufacturing sector smaller than it would otherwise have been. As we will emphasize below, it is treacherous to assume that a trade deficit represents forgone domestic output. Closing the trade deficit need not imply growing domestic output. It could simply imply shrinking domestic expenditure. Nonetheless, assume that trade deficits do represent forgone domestic output. More manufacturing activity from a smaller trade deficit would boost manufacturing's share in overall business output. This higher share, in turn, would imply higher overall business productivity. Thus, closing the trade deficit would raise aggregate productivity.

Do the data support this story? In 1991 the manufacturing trade deficit was $\$ 47$ billion, approximately 5 percent of manufacturing value added. Had the manufacturing sector been 5 percent larger thanks to elimination of the trade deficit, it would indeed have carried a larger weight in the business sector. But this larger weight would have in-

24. Gullickson (1992) corroborates our result. He estimates that multifactor productivity in U.S. manufacturing increased by 1.6 percent a year between 1979 and 1988 exactly the same rate recorded between 1948 and 1973 . He also demonstrates that manufacturing accounted for all of the 0.8 percent annual increase in multifactor productivity growth in the private business sector.

25. See Baily and Gordon (1988) for a more complete analysis. 
creased the level of business-sector productivity growth accumulated between 1979 and 1991 by only 0.3 percent. Eliminating the trade deficit, therefore, would not have appreciably boosted American productivity.

\section{International Comparisons}

Data on productivity and earnings in other countries are difficult to obtain. The BLS, however, does compile data on output and earnings per worker for France, Germany, Japan, and the United Kingdom. These data are reported in table 2. Several features are worth noting.

First, in contrast to the U.S. experience, real earnings in the four economies grew significantly over the decade. The result has been a convergence of foreign real earnings toward U.S. levels.

Second, the primary source of the difference in earnings behavior between the United States and other countries was the difference in the growth of nonmanufacturing output per employee. Table 2 decomposes overall productivity growth between the manufacturing and nonmanufacturing sectors of each country. Almost all of the U.S. productivity growth and a high share of the productivity growth in the United Kingdom occurred in manufacturing. In contrast in Japan, France, and Germany productivity growth in nonmanufacturing contributed 57 percent, 67 percent, and 75 percent, respectively, to the overall rise in productivity. These figures imply that productivity growth outside manufacturing (plus changes in the share of manufacturing in overall output) accounted for 70 percent, 91 percent, and more than 100 percent of the differences in overall productivity growth between the United States and Japan, France, and Germany, respectively. Differences between the United States and the United Kingdom, by contrast, reflected mainly manufacturing performance.

Third, in the three European economies a shift in income distribution toward profits slowed down the growth in product wages, and production and consumption wages grew at about the same pace. In these two respects, the three economies differed from the United States. Japan, however, resembled the United States. There, profit shares remained constant, but consumption wages grew more slowly than production wages. 
As noted in McKinsey, output per hour in the service sector remains higher in the United States than in other industrial economies. ${ }^{26}$ This American lead has been shrinking during the past two decades, however. Because most services are not traded, this improved relative performance abroad is likely to reflect domestic developments thereincreased education, increased investment rates, and technological improvements - rather than the removal of barriers to trade. ${ }^{27}$

It is striking how much attention has focused on relative U.S. manufacturing performance and how little on the slowdown of productivity growth in U.S. services. ${ }^{28}$ Before the quantitative importance of this productivity development has been taken into account, it is particularly inappropriate to interpret the convergence in international real wages as evidence of international trade's factor-price equalization (FPE). FPE is a basic result of standard international trade theory, which says that under certain conditions (including the use of identical technology and reasonably similar factor endowments), free trade equalizes factor prices across countries. It is important, therefore, to distinguish the international factor-price convergence caused by FPE from that caused by productivity or technological convergence. This distinction is especially critical because technological catch-up in the nontraded sector of follower nations might well improve, rather than reduce, real wages in the leading country. ${ }^{29}$

To conclude, we have found that trade played very little role in the performance of average real compensation in the United States in the 1980s. Consumption-deflated compensation lagged production-deflated compensation because of the relative rise in housing prices and the relative decline in investment prices (especially computers). Compensation grew slowly mainly because productivity in the service sector grew slowly. These results indicate that the most important determinants of U.S. average compensation in the 1980s lay in the behavior of the domestic economy.

26. McKinsey Global Institute (1992).

27. Foreign direct investment, on the other hand, may have contributed to this convergence. According to the United Nations (UNCTC, 1991), in 1970 foreign direct investment in services accounted for 25 percent of the global stock of foreign direct investment. By the late 1980 s the share was close to 50 percent.

28. For a focus on services instead, see the paper by Baily in this volume.

29. Much depends on the effect of foreign income growth on the terms of trade. 


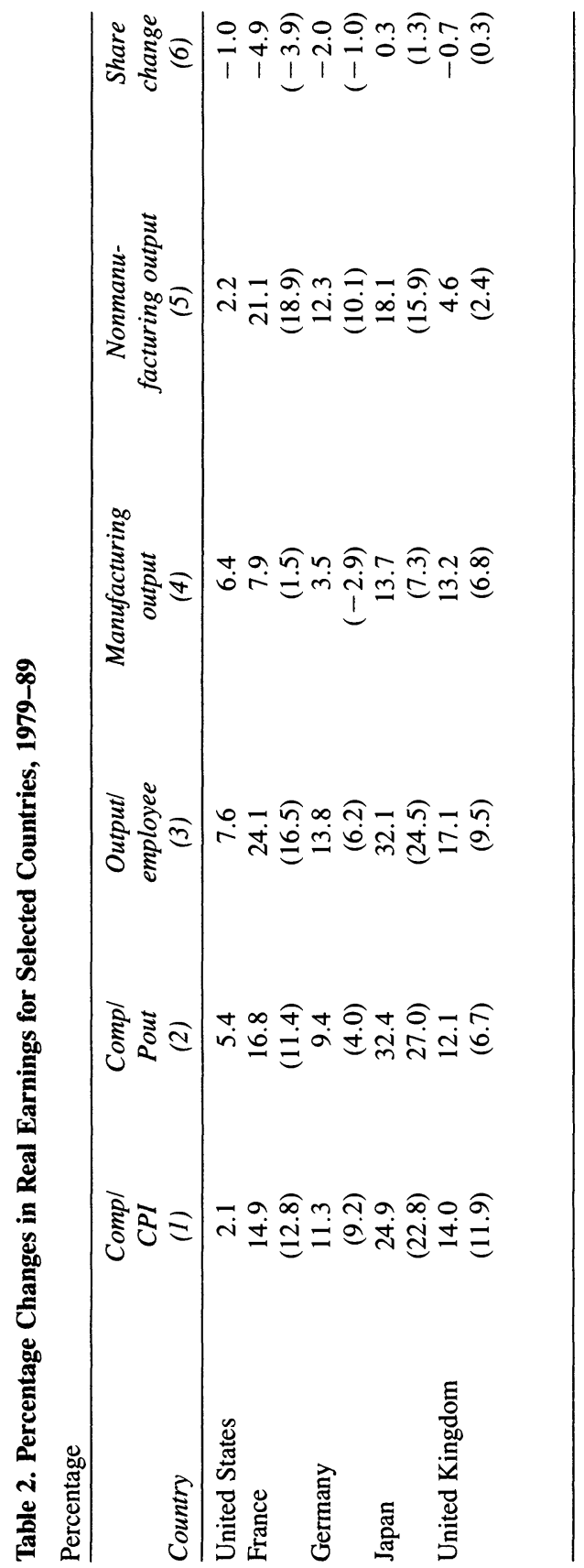




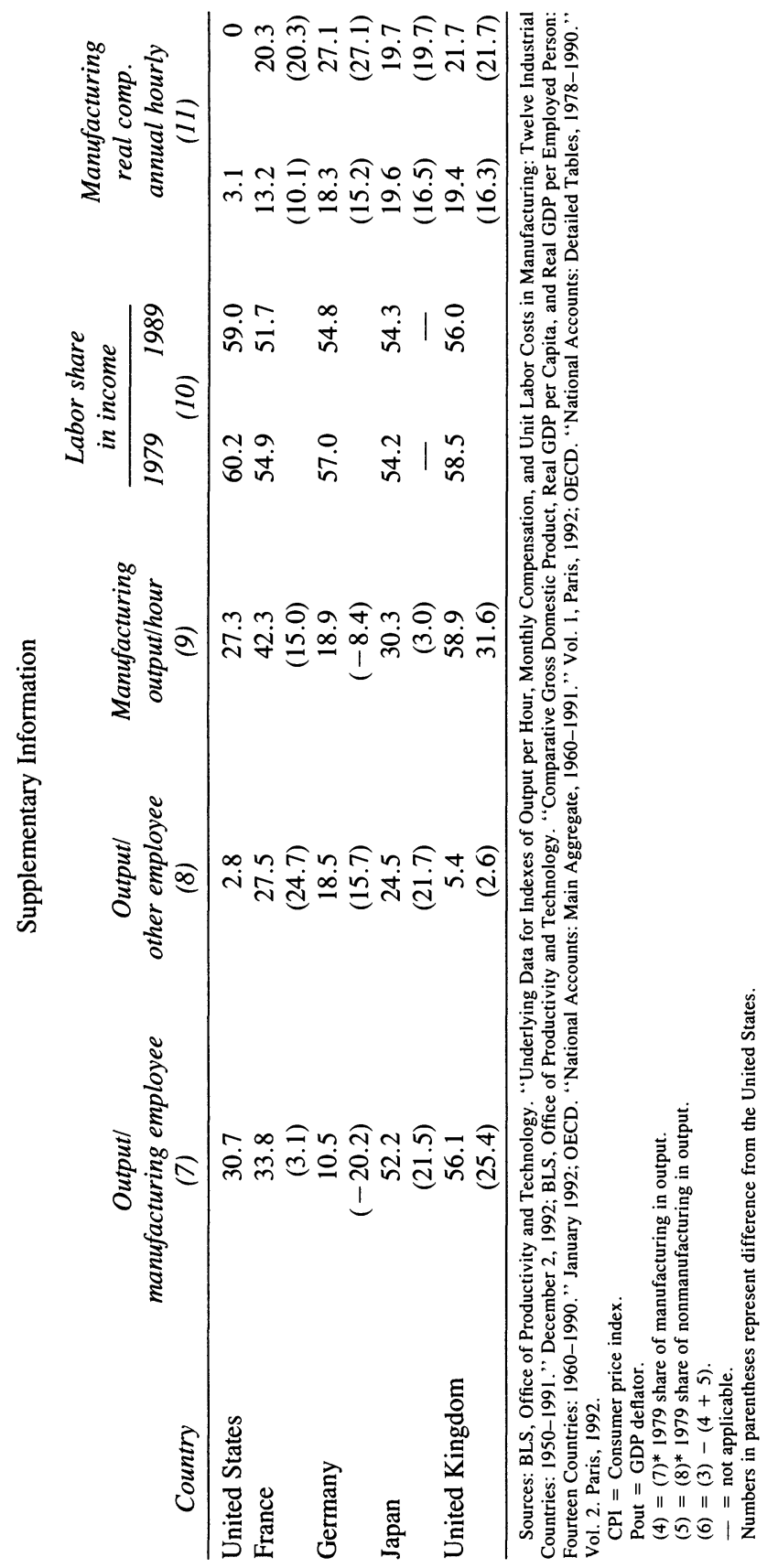


Figure 5. Evolution of Wages and Employment in Manufacturing
A. Ratio of nonproduction to production wages

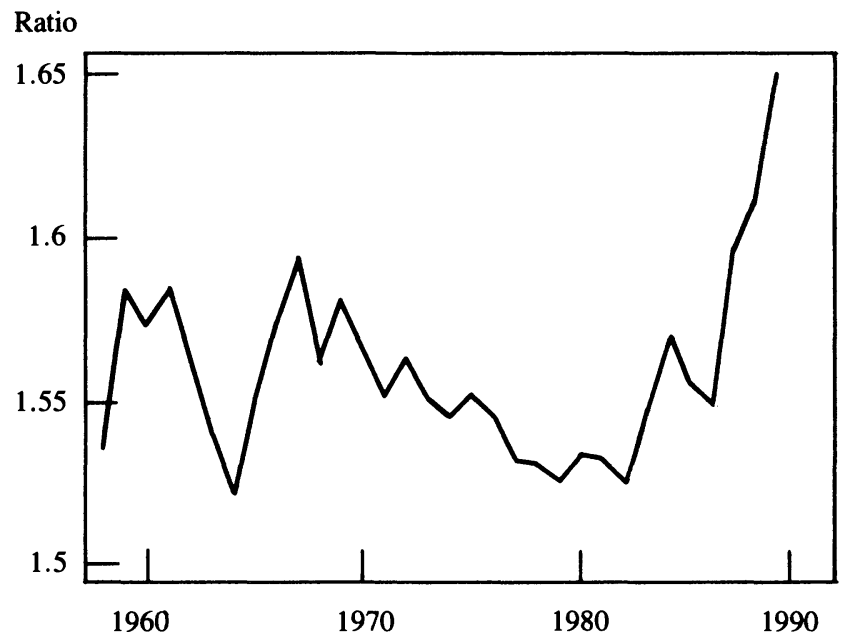

B. Ratio of nonproduction to production employment

Ratio

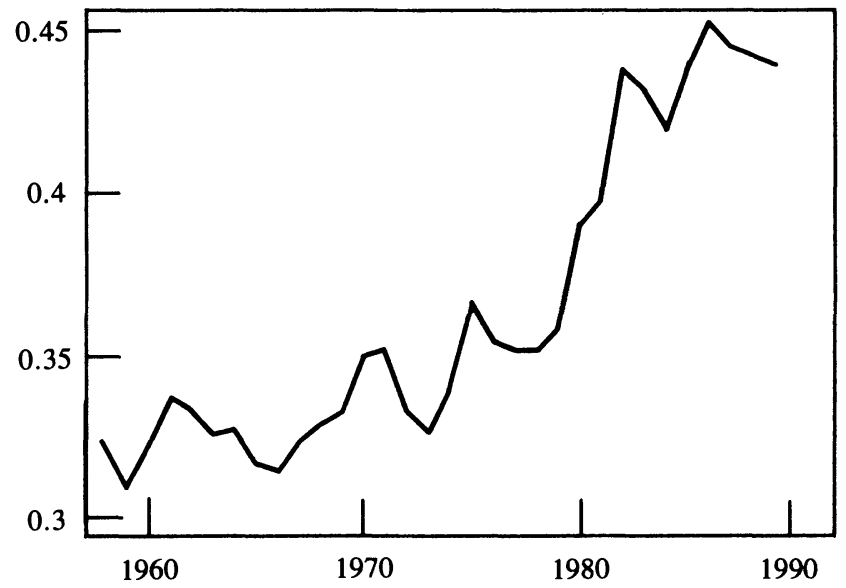

Source: Wage and employment data come from the NBER's Trade and Immigration Data Base. Wages are average wages; the ratio for labor employed is for all manufacturing industries taken together. 


\section{Relative Wage Performance}

We have calculated that in American manufacturing between 1979 and 1989, the ratio of mean annual wages of nonproduction workers to production workers rose by nearly 10 percent (figure 5A). ${ }^{30}$ This fact corroborates the evidence presented in the introduction on growing wage inequality, and it is worrisome for two reasons. First, the increased wage divergence sharply reverses the trend from 1945 until 1979 of wage convergence between production and nonproduction workers. Second, sluggish average real wages and diverging relative wages imply that unskilled workers actually suffered declines in real wages in the 1980 s.

One obvious explanation for this divergence is relative labor supply. All other things held constant, the wage differential between skilled and unskilled labor should grow if the supply of unskilled labor grows more than the supply of skilled labor. Studies suggest that shifts in relative supplies of labor in the 1980s may explain some of the wage behavior, but they also suggest that most of the shift remains to be attributed to demand. ${ }^{31}$ Indeed, in the 1980s college graduates and women, two groups experiencing rising relative wages, also experienced rising relative supply. White-collar occupations constituted 67.2 percent of employment in 1983, and they represented 90 percent of the rise in employment between 1983 and 1990. Similarly, managerial and professional specialty occupations accounted for 24 percent of employment in 1983 and 45.7 percent of the growth between 1983 and $1990 .^{32}$

30. In 1979 the mean wage of nonproduction workers in manufacturing was $\$ 19,517$, and the mean wage for production workers was $\$ 12,829$. In 1989 these wages were $\$ 34,866$ and $\$ 21,112$, respectively. Note that these wage measures do not include compensation such as health insurance. The previous section noted that total compensation rather than just wages is the appropriate measure of factor returns. Unfortunately, data on total compensation that distinguish between nonproduction and production workers were not readily available. Therefore, we use the wage data that we have in light of this caveat.

31. See, for example, Borjas, Freeman, and Katz (1992) on the immigration of unskilled workers, and Katz and Murphy (1992) on the slowdown of the growth in welleducated entrants. See Murphy and Welch (1992) and Bound and Johnson (1992) for convincing arguments on demand as a major explanation for the shift in relative labor supplies.

32. The mapping is quite tight between the nonproduction-production distinction and the white-collar-blue-collar distinction. We define as "white-collar" occupations 
If manufacturing shifts its demand away from production workers and toward nonproduction workers, the wage differential between the two groups should grow. A second stylized fact from the data supports this labor-demand story. Figure 5B shows the evolution of the ratio of nonproduction to production workers employed in manufacturing. The ratio rose 25 percent between 1979 and 1989 , from 0.35 to 0.44 . This rise was much sharper than the gentle upward trend of the earlier postwar decades.

Thus both the relative wages and the relative employment of nonproduction workers rose in American manufacturing in the 1980s. This combination indicates that the labor-demand mix must have shifted toward nonproduction labor. ${ }^{33}$

Several facts support this indication. Between 1983 (the earliest year for which consistent occupation data are available) and 1990, the rise in nonproduction workers in manufacturing was heavily concentrated in two occupational categories: managers and professional specialties. During these seven years, employment in these categories grew by 25 percent, while employment in total manufacturing grew by just 4.7 percent. Growth in these two categories constituted 91.5 percent of all employment growth in manufacturing during this period. This trend has continued despite the perception that middle-level managers in manufacturing are being laid off. Between March 1990 and March 1992, overall employment in manufacturing declined by 1.6 million workers, or 7.6 percent, but employment of managers and the professional specialties actually increased by 0.7 percent.

There is no doubt that the labor-demand mix shifted toward nonproduction labor. The question thus becomes why the demand for nonproduction workers in manufacturing has been so strong.

\section{Framework}

To determine the relative contributions of trade and technology to shifts in labor demand, consider a general production function for industry $j$ at time $t$.

such as managerial and professional specialty; technical, sales, and administrative support; and service occupations. See the BLS Handbook.

33. A simple exercise of drawing relative-supply and relative-demand schedules shows that relative wages and relative employment can rise only if the relative-demand schedule shifts toward nonproduction labor, regardless of what happens to the relativesupply schedule. 


$$
Q_{j t}=\Theta_{j t} F^{j}\left(S_{j t}, U_{j t}, K_{j t}\right),
$$

where $Q_{j t}$ is the output of industry $j, F^{j}(\cdot)$ is the time-invariant production function of industry $j$, and $\Theta_{j t}$ is the Hicks-neutral technology parameter for industry $j$ at time $t$ that boosts the productivity of any given combination of inputs. The factors of production employed at time $t$ are capital $\left(K_{t}\right)$, skilled (or nonproduction) labor $\left(S_{t}\right)$, and unskilled (or production) labor $\left(U_{t}\right)$. The demand schedule for each factor is the appropriate first-order condition of the profit-maximization problem. At time $t$, industry $j$ demands factor $i$ according to

$$
w_{i j t}=P_{j t} \times \Theta_{j t} \times F_{i t}^{j}(\cdot) .
$$

Here, $w_{i j t}$ equals factor $i$ 's marginal revenue product in industry $j$ at time $t .{ }^{34}$ It is the amount that industry $j$ is willing to pay factor $i$ for a unit of its services. In equilibrium, this amount equals the actual wage set by the market. $P_{j t}$ is the exogenously given price of output in industry $j$ at time $t$, and $F_{i t}^{j}(\cdot)$ is the partial derivative of $F^{j}(\cdot)$ with respect to factor $i$ at time $t$.

To specify the labor market completely, one must add a supply schedule for factor $i$ in industry $j$. The quantity of factor $i$ supplied to industry $j$ probably depends on at least the wage that factor $i$ can receive both in industry $j$ and elsewhere, that is, on $w_{i j}$ and $w_{i-j}$. Quantity supplied probably does not depend on $P_{j t}$ or $\Theta_{j t}$, however. In this case shifts in $P_{j t}$ and $\Theta_{j t}$ identify the supply schedule as shifts in the demand schedule trace it out.

In the following discussion we assume that the schedules are parameterized as described. We can therefore study shifts in the demand for labor by studying shifts in $P_{j t}$ and $\Theta_{j t}$. First, we analyze how international trade changes $P_{j t}$. Then we analyze how technological progress changes $\Theta_{j t}$.

\section{International Trade Theory and Relative Wages}

The classic Hecksher-Ohlin-Samuelson (HOS) trade theory assumes a world of constant returns to scale and perfect competition. One of the basic implications of this theory, typically set in a two-good world with

34. This equation is derived, as was equation 1. Here, however, we distinguish between labor types and among industries. We also represent $m p p_{\mathrm{ijt}}$ as the product of $\Theta_{j t}$ and $F_{i t}^{j}(\cdot)$. 


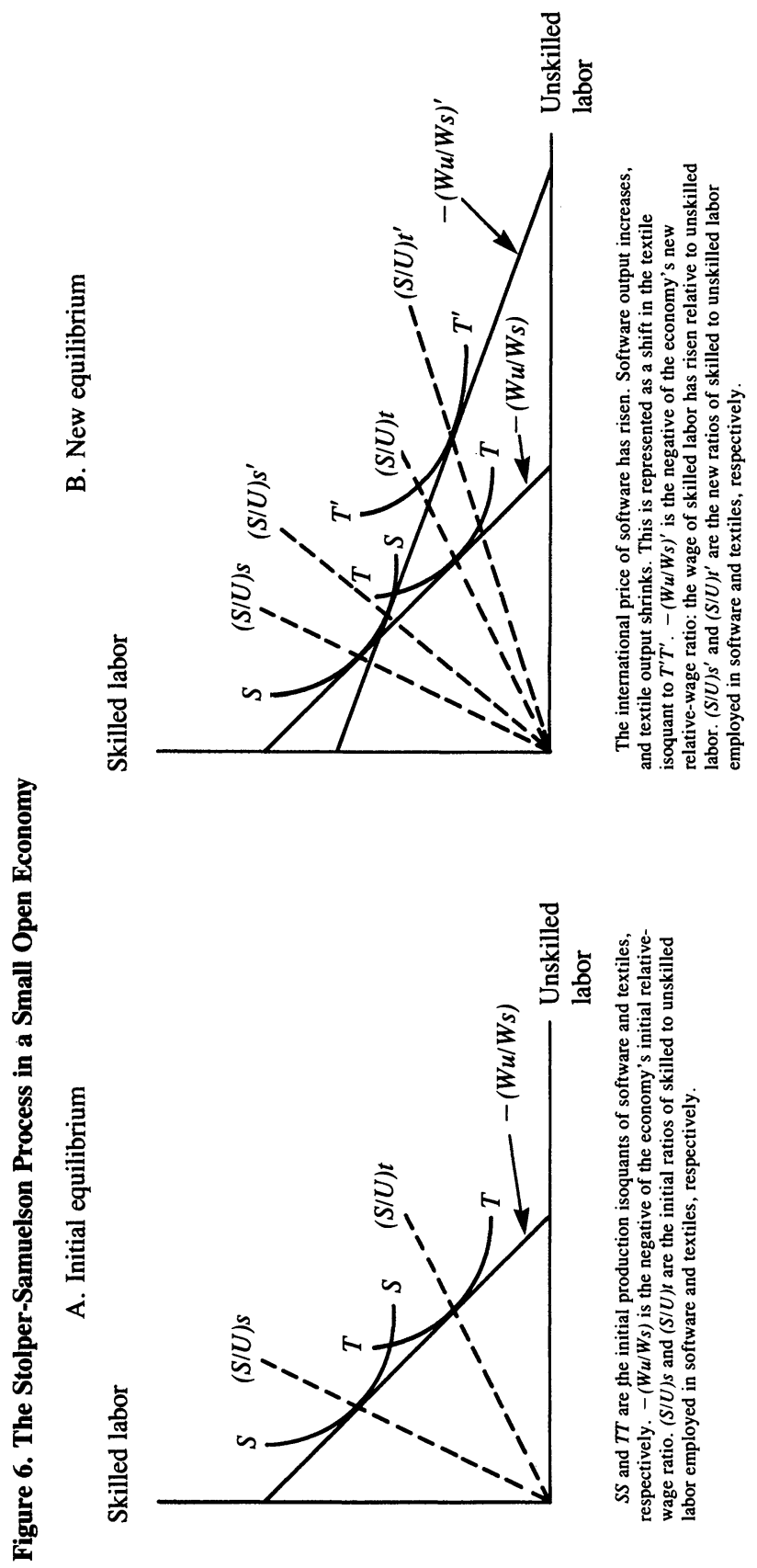


trade, is the Stolper-Samuelson theorem. This theorem states that an increase in the price of a product raises the return to factors used relatively intensively in the production of that good and lowers the return to factors used relatively sparsely. International trade thus redistributes income by changing the terms of trade.

To understand the Stolper-Samuelson process, consider a small open economy that produces two products, software and textiles, with two factors, skilled and unskilled labor. "Open' means that this country freely trades both goods with the rest of the world. "Small" means that this country's production and consumption choices do not influence its terms of trade. Instead, these relative prices are determined in the rest of the world. Furthermore, suppose that software uses skilled labor relatively intensively. ${ }^{35}$ Initially, the country settles at some equilibrium output mix of software and textiles. To produce this mix, firms employ the country's skilled and unskilled labor. The labor market generates an equilibrium wage for each type of labor; at this wage the quantity of labor demanded by firms equals the total quantity supplied in the economy.

We can illustrate this equilibrium by choosing the production isoquants for software and textiles that correspond to their given relative price. In figure 6A these are drawn as $S S$ and $T T$, respectively. Note that $S S$ lies above and to the left of $T T$. This indicates that software uses skilled labor relatively intensively. If both goods are produced, both isoquants must be tangent to the line that indicates the ratio of factor prices, $\left(W_{s} / W_{u}\right)$. These tangency points indicate the ratios of skilled to unskilled labor $(S / U)_{s}$ and $(S / U)_{t}$ used to produce software and textiles, respectively. ${ }^{36}$

Now suppose that the international price of software rises. This is depicted in figure 6B as an outward shift in the relevant textile isoquant to $T^{\prime} T^{\prime}$. The country will seek to make more software and fewer textiles. Output in textiles declines, releasing some of both factors. Output

35. This is an assumption about the technology of production. It means that for any given relative wages, the ratio of skilled to unskilled labor employed in making one unit of software exceeds the ratio of skilled to unskilled labor employed in making one unit of textiles. Because there are only two goods and two factors in this economy and because software uses skilled labor relatively intensively, it follows that textiles use unskilled labor relatively intensively.

36. If technological capabilities are the same throughout the world, the unique relationship between the prices of goods and the prices of factors leads to FPE. 
in software expands, requiring more of both factors. Because software employs skilled labor relatively intensively, the overall economy's relative demand shifts toward skilled labor and away from unskilled labor. If factor prices remained constant, however, the factor quantities released by textiles would not match those demanded by software because of the different factor intensities of the goods. The textile industry would release too much unskilled labor and too little skilled labor relative to the demands of the software industry.

Wages must therefore change. The wage for unskilled labor falls, and the wage for skilled labor rises. The new equilibrium ratio of the relative price of factors is $\left(W_{s} / W_{u}\right)^{\prime}>\left(W_{s} / W_{u}\right)$. This higher ratio induces firms to substitute away from skilled labor and toward unskilled labor, and this substitution lowers the ratio of skilled to unskilled labor employed in each industry. (In figure 6B, this substitution is represented as a flattening of each industry's $(S / U)$ ray to $(S / U)^{\prime}$.) Textiles thus releases less unskilled labor and more skilled labor relative to what it would have released without the wage change. Similarly, software demands more unskilled labor and less skilled labor relative to what it would have required without the wage change. Wages move just enough to reemploy all labor; at this point the economy attains its new equilibrium.

In the new equilibrium the economy makes more software and fewer textiles. This new output bundle implies a shift in the economy's relative factor demand toward skilled labor and away from unskilled labor. This shift has two important effects. It raises the wage for skilled labor and lowers the wage for unskilled labor. It also lowers the ratio of skilled to unskilled labor employed in both industries. Overall, changed terms of trade have translated into changed factor returns and changed factor-employment ratios by shifting the demand for these factors. With reference to equation 6 , the $w_{i j t}$ s change because both the $P_{j t} \mathrm{~s}$ and the $F_{i t}^{j}(\cdot)$ s change (the latter because of the new relative employment levels in all industries). Thus, it is not trade volumes that matter in the StolperSamuelson process. It is the change in prices of traded goods.

We have presented the Stolper-Samuelson process in a very simple model. One might wonder whether the process still operates in more complicated-yet more realistic-models. The short answer is that it does. The model can be extended, for example, by allowing either or both of the industries to be imperfectly competitive thanks to increasing 
returns to scale. Helpman and Krugman lay out the basic imperfectcompetition models, and they find that Stolper-Samuelson still operates. ${ }^{37}$ The model can also be extended by increasing the number of factors of production and goods. Ethier studies how Stolper-Samuelson and other theorems generalize in a model with many factors and many goods. ${ }^{38} \mathrm{He}$ finds that Stolper-Samuelson still operates but differently, depending on the number of goods and factors. If the number of factors equals the number of goods, the model can identify, after a change in a good's price, the factor whose price rises in terms of every good and the factor whose price falls in terms of every good. If the number of factors does not equal the number of goods, the model cannot unambiguously identify these two factors. We acknowledge this qualification but assume in the work that follows that the simple Stolper-Samuelson story can be applied to the data. As a first approximation we think that this is a reasonable assumption.

\section{Existing Work on Trade and Relative Wages}

Did this process help increase the relative wages of skilled workers in the United States in the 1980s? Surprisingly, no study of America's income distribution in the 1980s has explicitly considered this question. ${ }^{39}$ Instead, studies of relative wages that look at the role of international trade have focused on either trade volumes and trade deficits or the effect of changes in the prices of traded goods on relative industry wages. ${ }^{40,41}$

37. Helpman and Krugman (1985).

38. Ethier (1984).

39. The one exception is Leamer (1992), who applies Stolper-Samuelson to estimate the impact of the North American Trade Agreement on labor and capital in the United States. In particular, he exploits the reciprocity between the Rybczynski and StolperSamuelson theorems by first estimating Rybczynski partial derivatives in production functions and then calling these estimates of Stolper-Samuelson partial derivatives. The logic of this method is clear, but Leamer's assumptions about the empirical applicability of reciprocity are debatable. In particular, trade theory says that Rybczynski partial derivatives are not well defined when the number of goods exceeds the number of factors.

40. On the first focus, see Borjas, Freeman, and Katz (1992); Davis (1992); Katz and Murphy (1992); and Murphy and Welch (1992). On the second, see Revenga (1992).

41. Bound and Johnson (1992) find some role in the overall changes in the premium earned by male college graduates relative to high school graduates for industry-specific effects. Of the 0.163 change in the ratio of earnings, they ascribed 0.016 to changes in shares accounted for by high- and low-wage industries, 0.02 to industry wage effects, and 0.013 to changes in the incidence of unionism. 
The studies that calculate the quantities of factors embodied in trade volumes or the trade deficit do not relate precisely to the StolperSamuelson theorem. For example, Borjas, Freeman, and Katz calculate the quantities of skilled and unskilled labor embodied in the U.S. trade deficits up through 1987 and call these quantities the "international factors" that influence wages. ${ }^{42}$ Borjas and his colleagues reason that these embodied labor supplies should be combined with the endowment of factors in the United States to obtain "effective" labor supplies in the United States. All other things equal, a large effective supply of a factor lowers its return. Because the United States tends to import unskilled-labor-intensive products, larger trade deficits in the $1980 \mathrm{~s}$ meant a larger relative effective supply of - and therefore a lower relative wage for-unskilled labor. ${ }^{43}$

Borjas, Freeman, and Katz conclude that U.S. trade deficits accounted for no more than 15 percent of the growth in inequality of U.S. wages. When the United States' trading partners are considered, it is not surprising that estimates of the factor supplies embodied in U.S. trade indicate relatively small effects on wages. In 1990,70 percent of U.S. manufacturing imports came from members of the Organization for Economic Cooperation and Development (OECD)—countries with endowments and wage structures very similar to those in the United States. In 1980 hourly compensation in other OECD countries was 83 percent of U.S. levels. This dropped to 64 percent by 1985 but then increased to 103 percent by $1990 .{ }^{44}$ In 1981 only 25 percent of U.S. manufacturing imports came from developing nations. By 1990 this share had increased to only 30 percent. ${ }^{45}$

Although the approach used by Borjas, Freeman, and Katz enjoys a long tradition, it is rather weakly grounded in standard trade theory.

42. Other examples of this approach include Lawrence (1984) and Kreuger (1991).

43. Policymakers sometimes use a particularly egregious version of this approach. They use a rule of thumb that says each $\$ 1$ billion of manufacturing output represents twenty thousand jobs. With this rule, they argue that a trade deficit of $\$ 100$ billion represents two million American jobs lost.

44. European Community wages were the same as U.S. wages in 1980 and are 15 percent higher today. Wages in the newly industrializing countries of Asia were 12 percent of U.S. levels in 1980 and are 25 percent today. Overall, on a weighted average with twenty-four foreign countries, foreign wages have increased from 72 percent to 88 percent of U.S. levels.

45. As a percentage of GDP, however, manufacturing imports from developing nations grew during the 1980 s, from 1.2 percent in 1981 to 2.1 percent in 1990 . 
Standard trade theory does discuss effective factor supplies, but it does not develop clear empirical tests for their effect on relative wages. Indeed, it suggests that trade deficits per se have no necessary relationship to factor returns. ${ }^{46}$ That is because trade deficits depend on both production and consumption activity: they are the excess of expenditure over production. ${ }^{47}$ The Stolper-Samuelson theorem, however, deals only with production activity: shifts in production prompted by shifts in the terms of trade. Changes in the trade deficit that leave the terms of trade unchanged do not change relative factor returns.

To clarify this point, return to our small open economy. Suppose that it is at full employment with balanced trade and that its residents decide to consume more than they produce. They import more and pay for this trade deficit with a capital account inflow. Obviously, because the economy remains fully employed, the trade deficit does not cost jobs. Moreover, because the economy is small, the terms of trade do not change-and this means that relative factor returns do not change. Domestic spending is simply exceeding the economy's productive potential. ${ }^{48}$ But the trade deficit does change the country's effective factor supplies as defined by Borjas, Freeman, and Katz. They would therefore incorrectly conclude that relative factor returns must change.

As Bhagwati has emphasized, relative price changes are the critical intervening variable in the chain of causation from trade to factor prices. ${ }^{49}$ Ex post trade volumes are a poor measure of the ex ante pressures generated by trade. If international competition forced U.S.

46. Some empirical work has used factor endowments to test trade theory results other than the Stolper-Samuelson theorem. For example, Bowen, Leamer, and Sveikauskas (1987) use effective factor supplies to test the law of comparative advantage. In addition, some theoretical work has linked effective factor supplies to factor returns. Deardorff and Staiger (1988) discuss the conditions under which changes in the factor content of trade can relate to changes in relative factor prices. Unfortunately, when the model does not restrict preferences and technology to be Cobb-Douglas, only average relationships can be derived between factor content and factor returns. Deardorff and Staiger do not lay out an empirical strategy for testing their model's results, so how exactly Borjas, Freeman, and Katz (1992) relate to their work is unclear. As for the relationship between trade deficits and factor returns, think of the transfer problem.

47. The entire literature on the transfer problem is devoted to determining the direction in which a trade deficit (or the accompanying international transfer of capital) will move the terms of trade.

48. If the country is large, the terms of trade could move in either direction, depending on demand patterns.

49. Bhagwati (1991). 
workers to lower their wages, domestic firms might be able to hold on to their domestic market shares. By examining only trade flows, however, one might conclude that trade had no impact on wages. In principle, even if trade flows are small, changes in the prices of traded goods could have large effects on the prices (and thus factor returns) of domestically produced substitutes. All of these considerations suggest that prices, rather than quantities, provide a better picture of the shocks originating from trade.

\section{Empirical Evidence of Stolper-Samuelson}

To explore the implications of the Stolper-Samuelson theorem, we examined the data for relationships consistent with the process's working. All other things equal in the Stolper-Samuelson framework, a rising relative wage of skilled labor should manifest itself in two relationships: first, a fall in all industries in the ratio of skilled to unskilled labor employed, and, second, an increase in the international price of skilledlabor-intensive products relative to those of unskilled-labor-intensive products. We consider each of these propositions in turn.

Our data set covers the U.S. manufacturing sector through 1989. Data on prices and quantities of inputs and outputs come from the Trade and Immigration Data Base of the National Bureau of Economic Research. Data on U.S. terms of trade come from the export and import price indexes produced by the BLS. ${ }^{50} \mathrm{We}$ have limited ourselves to manufacturing because very little data exist on trade in services. Because trade in manufactures constitutes nearly 70 percent of total U.S. trade, however, the Stolper-Samuelson process is unlikely to have a large role in overall trade without having a large role in manufacturing trade..$^{51}$

50. The export and import price indexes are generated from quarterly surveys of firms engaged in trade. The NBER data base draws primarily from the Annual Survey of Manufactures; see Abowd and Freeman (1991, introduction and summary) for a detailed description of this data base. Recall that in our data set "skilled labor" is defined as nonproduction labor and that "unskilled labor"' is defined as production labor. See the appendix for more on this. In addition, all SIC classifications in this data set come from the revision \#2 scheme. Revision \#3 replaced \#2 starting in 1988, and it redesignated about 25 percent of \#2's industries. All data from 1988 and 1989 have been concorded back to revision \#2.

51. The United States has a comparative advantage in nonproduction-labor-intensive products. In 1979 the exports-weighted ratio of nonproduction to production labor em- 
First, we consider whether industries experienced a fall in the ratio of nonproduction to production labor employed. If the Stolper-Samuelson process alone had influenced American wages in the 1980s, rising relative wages of nonproduction labor would have compelled all industries to substitute toward production labor. Figure 7 checks whether industries did substitute in this way. It plots the percentage change between 1979 and 1989 of relative wages and relative employment in manufacturing industries disaggregated at the two-, three-, and fourdigit SIC levels. Higher relative wages of nonproduction labor combined with a lower ratio of nonproduction to production labor employed would move industries into each of the upper-left quadrants of figure 7 .

Regardless of the level of disaggregation, however, only about 10 percent of all industries moved this way. ${ }^{52}$ Indeed, one of the remarkable features of American manufacturing in the 1980s was a pervasive increase in the ratio of nonproduction to production workers employed-exactly the opposite of the HOS prediction. At every level of disaggregation, at least half of all industries (measured by share of total manufacturing employment) moved to a new equilibrium in the upperright quadrant. This equilibrium entails both higher relative wages and higher relative employment of nonproduction labor. Thus, the majority of industries accompanied rising relative wages with rising, not falling, relative employment. So figure 7 indicates that Stolper-Samuelson was not the predominant influence on relative labor demand in the 1980s.

Two points should be emphasized. First, we have conducted our analysis at several levels of disaggregation to eliminate the possibility that outsourcing was an important reason for the shifts in relative labor use. By using industry data to explore the Stolper-Samuelson effects, we assume that we can identify each product with a unique industry and each industry with a unique production process. In practice, however, industries may make products using processes that differ in their factor intensity. For example, the production of semiconductors could involve both research and development $(R \& D)$, which uses skilled labor, and assembly, which uses unskilled labor. The availability of cheaper foreign labor might result not in the shrinking of entire indus-

ployed in U.S. export industries was 0.501 ; the analogous ratio for imports was 0.384 . In 1989 these ratios were 0.539 and 0.433 , respectively.

52. At the two-digit level, 8.2 percent; at the three-digit level, 9.8 percent; and at the four-digit level, 9.5 percent. 
Figure 7. Percentage Changes in the 1980s in the Relative Wages and Relative Employment of Nonproduction and Production Labor in Manufacturing

A. Two-digit SIC industries

Percentage change in relative wages

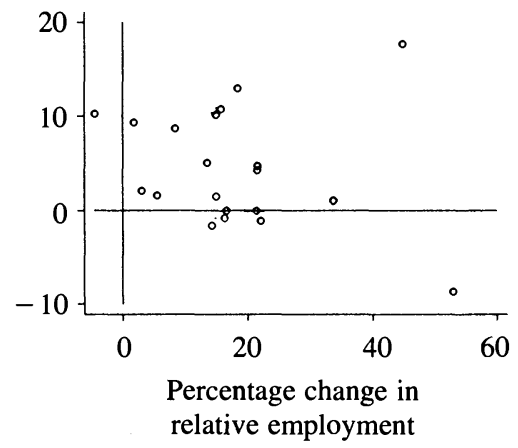

C. Four-digit SIC industries

Percentage change in relative wages

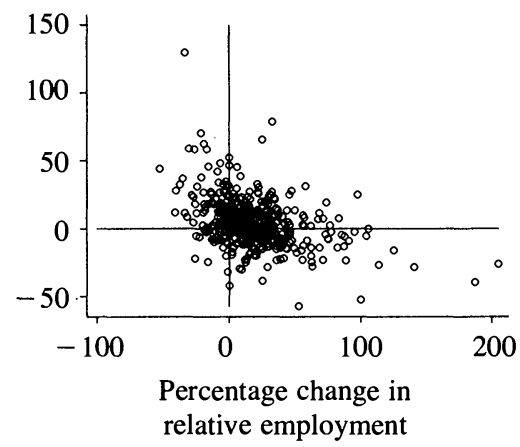

B. Three-digit SIC industries

Percentage change in relative wages

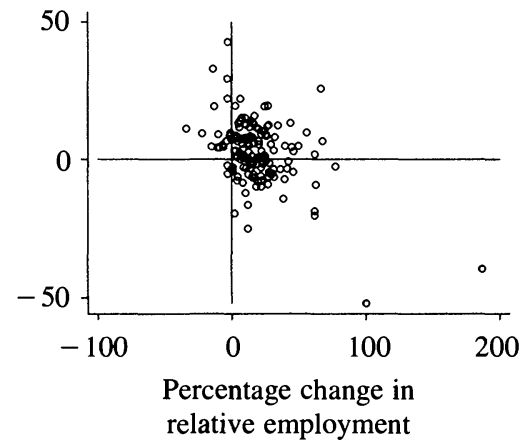

Source: Employment and wage data come from the NBER's Trade and Immigration Data Base.

tries, but rather in the international migration of particular production processes within an industry. This outsourcing could be confused with a change in production techniques if the data are analyzed at an aggregate level. The foreign outsourcing of assembly operations in semiconductors, for example, would raise skill intensity in the data for the industry as a whole because of the shrinking assembly activities, 
whereas separate data on $R \& D$ and assembly might indicate no shift in relative factor use. ${ }^{53}$

The fact that the rise in ratio of nonproduction to production workers is as pervasive at the four-digit level as it is at the two-digit level suggests that the rise does not reflect outsourcing. Berman, Bound, and Griliches corroborate this evidence against outsourcing. ${ }^{54}$ They note that the 1987 Annual Survey of Manufactures reported that foreign materials constituted only 8 percent of all materials purchased in manufacturing in 1987. Moreover, only a small fraction of materials purchased typically come from an establishment's own industry: 2 percent of materials originated in the same four-digit SIC category, 7 percent in the same three-digit category. They calculate that replacing all outsourcing with domestic activity would raise manufacturing employment of production workers by just 2.8 percent.

Second, all we can conclude from examining the relative employment ratios is that the Stolper-Samuelson effect was dominated by some larger effect. The sum of these effects was that most industries employed relatively more, not relatively less, nonproduction labor. We cannot yet say anything about the absolute size of the Stolper-Samuelson effect. Perhaps it was large; perhaps it was nonexistent.

To determine the absolute size of this effect, we examine international prices. Figures $8 \mathrm{~A}$ and $8 \mathrm{~B}$ graph percentage changes over the 1980 s in industries' import prices against the ratio of nonproduction to production labor employed in these industries in 1980. In figures 9A and 9B the import prices are replaced with export prices. In each pair of figures, the first classifies industries at the two-digit SIC level, and the second at the three-digit SIC level. ${ }^{55}$

Nonproduction-labor-intensive products are those that employ a high

53. The BEA collects the most comprehensive data on the activity of multinationals. It does not release all these data by country at the three-digit SIC level of disaggregation, however, to avoid revealing the identity of individual corporations.

54. Berman, Bound, and Griliches (1993).

55. Unfortunately, the BLS does not report prices for all industries between 1979 and 1989. The import prices cover 93 percent of all manufacturing employment at the two-digit level and 50 percent at the three-digit level. The export prices cover 64 percent of all manufacturing employment at the two-digit level and 48 percent at the three-digit level. We assume that the price movements in these industries are reasonably representative. In addition, a minority of industries were not covered as far back as 1980 . Almost all of these, however, were covered by 1982 and were therefore included in the diagrams. 
Figure 8. Percentage Changes in the 1980s of Import Prices by Industry Versus the Nonproduction-Worker Intensity of Industries

A. Two-digit SIC industries

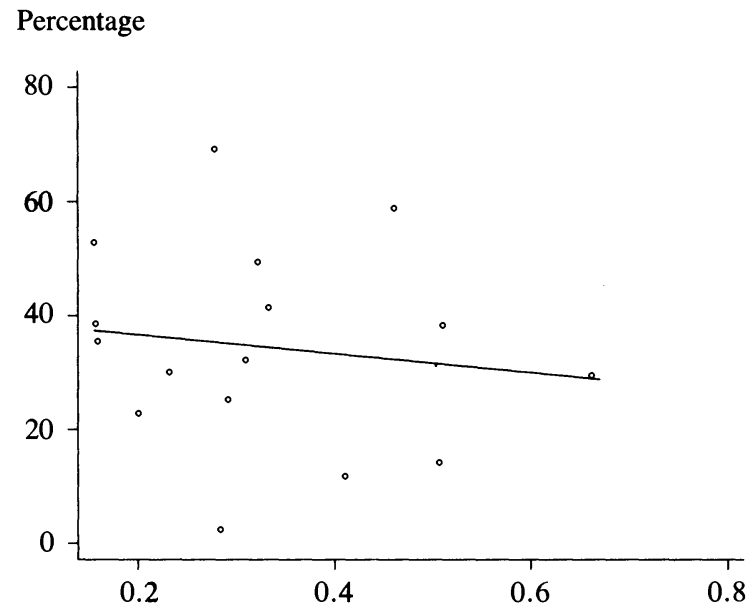

Ratio of nonproduction to production workers employed in 1980

B. Three-digit SIC industries

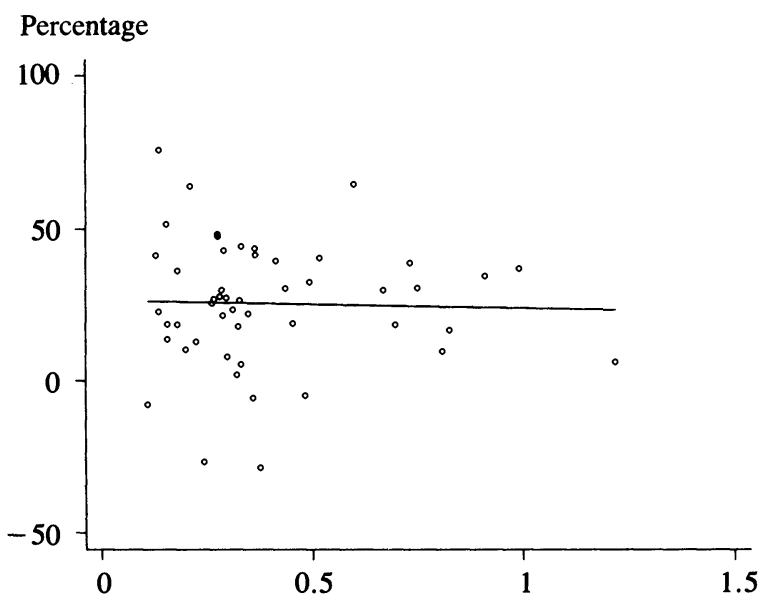

Ratio of nonproduction to production workers employed in 1980.

Source: Import and export prices come from the Bureau of Labor Statistics; employment data come from the NBER's Trade and Immigration Data Base. 
Figure 9. Percentage changes in the 1980s of Export Prices by Industry Versus the Nonproduction-Worker Intensity of Industries

A. Two-digit SIC industries

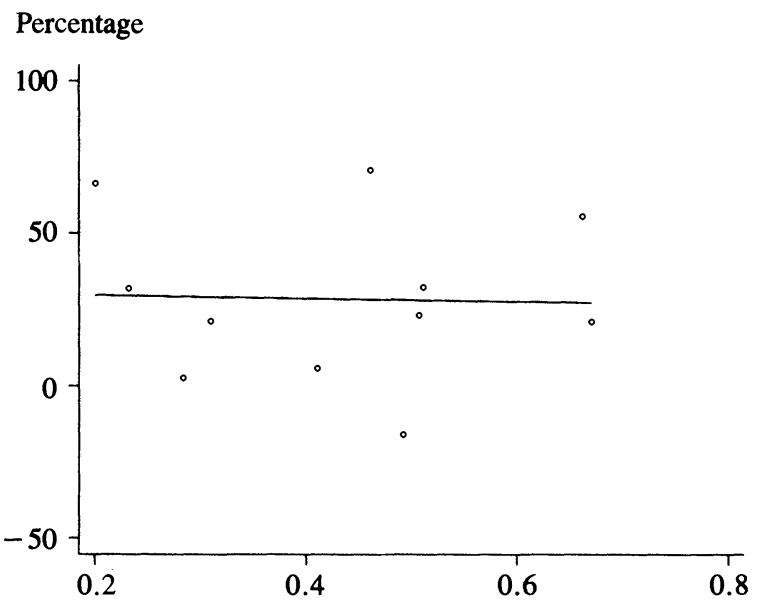

Ratio of nonproduction to production workers employed in 1980

B. Three-digit SIC industries

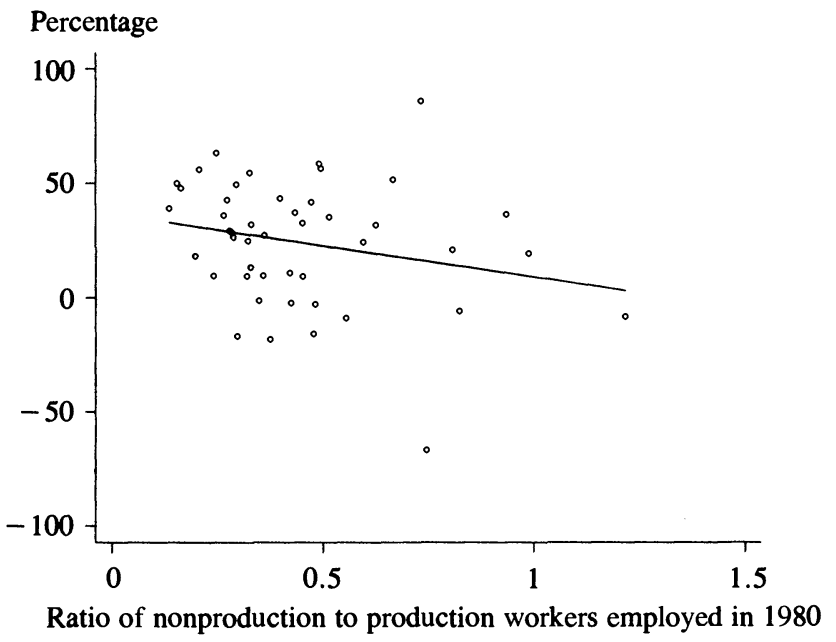

Source: Import and export prices come from the Bureau of Labor Statistics; employment data come from the NBER's Trade and Immigration Data Base. 
ratio of nonproduction to production labor. ${ }^{56}$ If Stolper-Samuelson had any influence at all, then the international prices of these products should have risen relative to the international prices of productionlabor-intensive products. But figures 8 and 9 do not indicate a rise in the relative price of nonproduction-labor-intensive goods. Instead, the trend lines suggest that the relative price of nonproduction-labor-intensive products actually fell. ${ }^{57}$

Weighted-average price increases corroborate this suggestion. For both import and export prices at the three-digit level, we have constructed two price indexes. One weights each industry's price rise by the industry's share in 1980 employment of nonproduction workers, the other by the industry's share in 1980 employment of production workers. ${ }^{58}$ As table 3 shows, import prices weighted by shares of nonproduction labor rose by 26 percent in the 1980 s. Weighted by shares of production labor, import prices rose by 28 percent. Similarly, export prices weighted by shares of nonproduction labor rose by 26 percent in the $1980 \mathrm{~s}$. Weighted by shares of production labor, they rose by 30 percent.

Thus, the data suggest that the Stolper-Samuelson process did not have much influence on American relative wages in the 1980s. In fact, because the relative price of nonproduction-labor-intensive products fell slightly, the Stolper-Samuelson process actually nudged relative wages toward greater equality. No regression analysis is needed to reach this conclusion. Determining that the relative international prices of U.S. nonproduction-labor-intensive products actually fell during the $1980 \mathrm{~s}$ is sufficient. ${ }^{59}$

56. To ensure that no factor-intensity reversals occurred during the decade that could change the results, we also plotted changes in the terms of trade against employment ratios calculated for 1985 and 1989. These plots were very similar to figures 8 and 9; they therefore have not been included.

57. These trend lines plot the estimated percentage price changes obtained from regressing actual percentage price changes on the ratio of skilled to unskilled labor employed and a constant. None of the four regressions estimated a coefficient on the ratio that was significantly negative at even the 10 percent level of significance.

58. These price indexes were also calculated using 1989 employment shares as weights. The results were virtually identical, so only the results with 1980 employment shares as weights are presented.

59. If we had seen the relative international prices of nonproduction-labor-intensive U.S. products rise, regression analysis would have been appropriate to determine the contribution of Stolper-Samuelson to U.S. wage changes relative to other factors such as technological progress. 
Table 3. Employment-Weighted Percentage Changes in International Prices and Hicks-Neutral Productivity, 1980-89

\begin{tabular}{lccc}
\hline & \multicolumn{3}{c}{ Percentage change, 1980-89 } \\
\cline { 2 - 4 } \multicolumn{1}{c}{ Industry } & $\begin{array}{c}\text { International } \\
\text { prices }\end{array}$ & $\begin{array}{c}\text { Hicks-neutral } \\
\text { technology }\end{array}$ & $\begin{array}{c}\text { Effective } \\
\text { prices }\end{array}$ \\
\hline Import-producing & & & \\
$\quad$ Nonproduction weights & 26.0 & 20.5 & 46.5 \\
Production weights & 28.1 & 11.9 & 40.0 \\
Difference & -2.1 & 8.6 & 6.5 \\
Export-producing & & & \\
$\quad$ Nonproduction weights & 26.3 & 18.6 & 44.9 \\
Production weights & 30.0 & 10.7 & 40.7 \\
Difference & -3.7 & 7.9 & 4.2 \\
\hline
\end{tabular}

Sources: International-price data come from the Bureau of Labor Statistics. Employment and technology (total-factor productivity) data come from the National Bureau of Economic Research's Trade and Immigration Data Base and Wayne Gray.

Notes: Nonproduction weights weigh each industry's price and technology change by that industry's share of total manufacturing employment of nonproduction labor in 1980. Production weights weigh each industry's price and technology change by that industry's share of total manufacturing employment of production labor in 1980 . All industries are defined at the three-digit SIC level.

\section{Technological Change and Relative Wages}

We have concluded that changes in the $P_{j t}$ s prompted by international trade did not contribute to the growing U.S. wage dispersion in the 1980s. This leaves changes in the Hicks-neutral technology parameters, the $\theta_{j t} \mathrm{~s}$. The $\theta_{j t} \mathrm{~s}$, like the $P_{j t} \mathrm{~s}$, are indexed only by industry. Changes in $\Theta_{j t} \mathrm{~s}$, therefore, shift the labor-demand equations, as do changes in the $P_{j t}$ s. Industries with rising $\Theta_{j t} \mathrm{~s}$ attract producers and shift relative factor demands, as do industries with rising $P_{j t}$ s. Thus, under the assumption of given prices, Hicks-neutral technological change occurring more rapidly in the nonproduction-labor-intensive industries should increase the relative wage of nonproduction labor.

We can therefore test for the influence of Hicks-neutral technical change on relative wages as we tested for the Stolper-Samuelson process. All other things equal, this change should manifest itself in two relationships similar to those analyzed for the Stolper-Samuelson process. First is a fall in all industries in the ratio of skilled to unskilled labor employed; second is greater Hicks-neutral technological progress for skilled-labor-intensive products relative to unskilled-labor-intensive products. Again, we examine each of these propositions in turn.

We measure growth of the $\theta_{j t} \mathrm{~s}$ as the growth of total factor produc- 
Figure 10. Percentage Changes in the 1980s of Total Factor Productivity by Industry versus the Nonproduction-Worker Intensity of Industries

A. Two-digit SIC industries

Percentage change in TFP

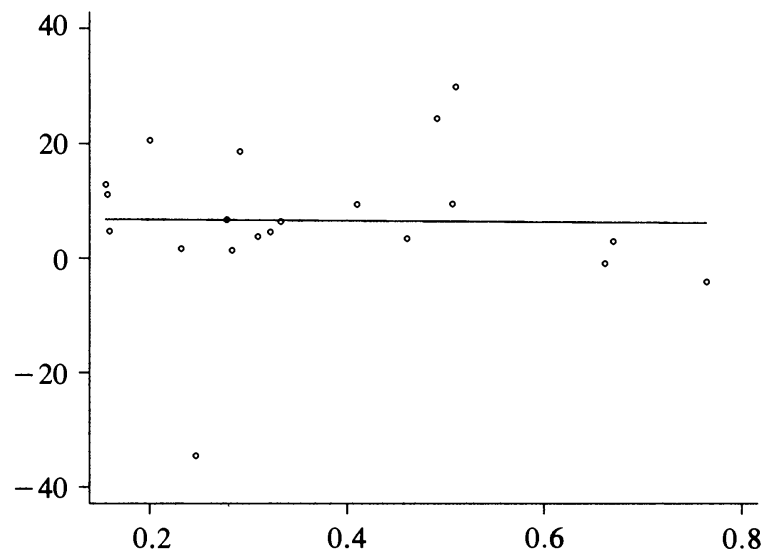

Ratio of nonproduction to production workers employed in 1980

B. Three-digit SIC industries

Percentage change in TFP

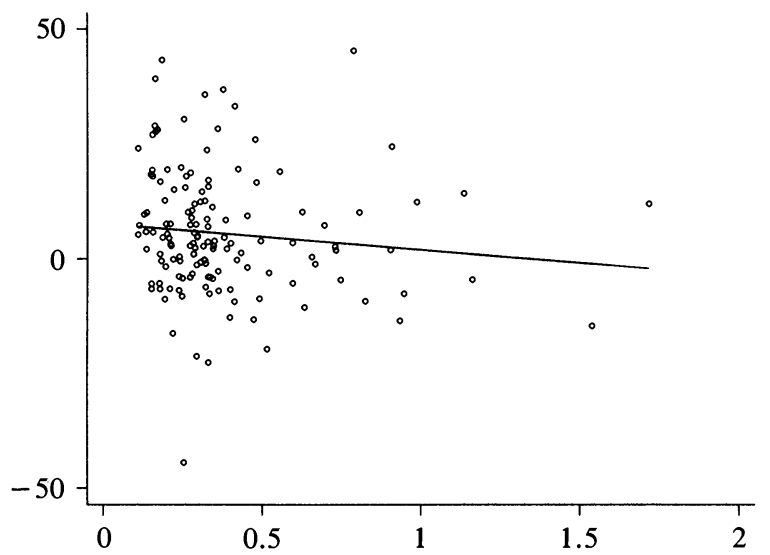

Ratio of nonproduction to production workers employed in 1980

Source: TFP data come from Wayne Gray; employment data come from the NBER's Trade and Immigration Data Base. 
tivity (TFP) in each industry $j$. The TFP growth for an industry is calculated as the growth of real output minus the weighted average of the growth of the costs of five real inputs: nonproduction labor, production labor, capital, energy, and intermediate materials. ${ }^{60}$ Transforming the annual changes into decade-long changes allows testing for their cumulative effect.

Figure 7 demonstrates that, as with international prices, Hicks-neutral technological change was not the predominant influence on relative labor demand in the 1980s. If it had been, industries would have moved into the upper-left quadrant as higher relative wages for nonproduction labor prompted lower ratios of nonproduction to production labor employed.

To check the absolute size of the effect of Hicks-neutral technological progress, look at figures $10 \mathrm{~A}$ and 10B. They graph percentage changes in industries' TFP during the 1980s against the ratio of nonproduction to production labor employed in these industries in 1980 . Figure 10A classifies industries at the two-digit SIC level; figure 10B at the three-digit SIC level. If Hicks-neutral technological change raised the relative wage of nonproduction labor, it did so by raising TFP more in the nonproduction-labor-intensive products. Figures $10 \mathrm{~A}$ and $10 \mathrm{~B}$ do not display such a change.

When technology increases are weighted by shares of production and nonproduction labor, however, we do find that technological change has been concentrated in industries that use nonproduction labor intensively. As we did for import and export prices at the three-digit level, we calculated two different weighted-average TFP increases for both export and import industries. ${ }^{61}$ Table 3 shows that in the import industries, TFP weighted by nonproduction-labor shares rose by 20.5 percent in the 1980s. Weighted by production-labor shares, however, TFP in the import industries rose by only 11.9 percent. Similarly, in the export industries, TFP weighted by nonproduction-labor shares rose by 18.6

60. Wayne Gray of Clark University in Massachusetts provided these TFP numbers. He assumed that cost shares sum to one and thereby calculated the cost share of capital as a residual. He also assumed that capacity utilization of capital remains constant. Real capital input is therefore a constant proportion of the real capital stock, and the rate of capital-input growth is simply the rate of capital-stock growth.

61. As was done with prices, these TFP indexes were also calculated using 1989 employment shares as weights. The results were virtually identical, so only the results with 1980 employment shares as weights are presented. 
percent in the 1980s. Weighted by production-labor shares, TFP in the export industries rose by only 10.7 percent.

Apparently, technological progress was concentrated in the skilledlabor-intensive industries. This helped raise the wages of skilled labor relative to unskilled labor. Indeed, it more than offset the effect on relative wages of the decline in the relative international price of nonproduction-labor-intensive products. To see this, define $\left(P_{j t} \times \Theta_{j t}\right)$ as the "effective price" of good $j$ at time $t .{ }^{62}$ The percentage change over time in a good's effective price is simply the sum of the percentage change in its international price and the percentage change in its Hicksneutral technology parameter. So adding the weighted-average increases in $P_{j t}$ and $\Theta_{j t}$ in table 3 yields the weighted-average increases in effective prices. The concentration of Hicks-neutral technological progress in nonproduction-labor-intensive industries offsets the concentration of international price increases in production-labor-intensive industries if and only if the nonproduction-weighted increase in effective prices exceeds the production-weighted increase.

Table 3 confirms that this was the case. For both exports and imports, the nonproduction-weighted increase in effective price was larger. This means that the combined effect of international prices and Hicks-neutral technology was to shift the labor-demand mix toward nonproduction labor. This shift helped raise the relative wage of nonproduction labor.

We can place this result in historical context by looking at the evolution of effective prices before 1980 . Unfortunately, data on terms of trade go back only to 1980 , so we use domestic price deflators instead. ${ }^{63}$ Table 4 lists effective-price changes (weighted as before) during three decades for all manufacturing industries at the three-digit SIC level. Notice that the difference between growth in effective prices weighted by nonproduction labor and growth weighted by production labor was 1.6 percent during the $1960 \mathrm{~s}, 1.7$ percent during the $1970 \mathrm{~s}$, and 4.1 percent during the $1980 \mathrm{~s}$. This sharp rise is consistent with the increased

62. Because both $P_{j t}$ and $\Theta_{j t}$ are indexed only by industry, we can call the product of the two an effective price. International trade theorists often use this construction to study simultaneously changes in the terms of trade and in technology.

63. These calculations assume that changes in these domestic price deflators tracked changes in international prices. This is a weaker assumption than the law of one price: it allows prices to differ across countries by some fixed constant. 
Table 4. Employment-Weighted Percentage Changes in Domestic Prices and Hicks-Neutral Productivity, 1960-89

\begin{tabular}{|c|c|c|c|}
\hline \multirow[b]{2}{*}{$\begin{array}{c}\text { All manufacturing } \\
\text { industries }\end{array}$} & \multicolumn{3}{|c|}{ Percentage change } \\
\hline & $\begin{array}{c}\text { Domestic } \\
\text { prices }\end{array}$ & $\begin{array}{c}\text { Hicks-neutral } \\
\text { technology }\end{array}$ & $\begin{array}{c}\text { Effective } \\
\text { prices }\end{array}$ \\
\hline \multicolumn{4}{|l|}{ 1960-69 } \\
\hline Nonproduction weights & 13.3 & 12.6 & 25.9 \\
\hline Production weights & 13.4 & 10.9 & 24.3 \\
\hline Difference & -0.1 & 1.7 & 1.6 \\
\hline \multicolumn{4}{|l|}{$1970-79$} \\
\hline Nonproduction weights & 88.1 & 13.4 & 101.5 \\
\hline Production weights & 93.3 & 6.5 & 99.8 \\
\hline Difference & -5.2 & 6.9 & 1.7 \\
\hline \multicolumn{4}{|l|}{$1980-89$} \\
\hline Nonproduction weights & 33.1 & 11.5 & 44.6 \\
\hline Production weights & 32.3 & 8.4 & 40.7 \\
\hline Difference & 0.8 & 3.1 & 3.9 \\
\hline
\end{tabular}

wage dispersion of the 1980 s. Notice, too, that in the 1970 s the concentration of technology growth in nonproduction-labor-intensive industries was even larger than in the 1980s. This concentration in the 1970s was overshadowed by the concentration of price increases in production-labor-intensive industries, however-precisely what would have been expected in light of the declining U.S. terms of trade.

So the growth pattern of Hicks-neutral technology offset the growth pattern of international prices. This helped shift the labor-demand mix toward nonproduction labor and thereby helped raise the relative wage of nonproduction labor. We should emphasize that because the relative supply of educated workers actually increased in the United States during the 1980 s, the demand effects must have been particularly powerful. The Hicks-neutral technology growth was not the predominant influence on the labor-demand mix, however. As discussed earlier, Hicks-neutral technology growth that is concentrated in the nonproduction-labor-intensive industries should lead to a falling ratio of nonpro- 
duction to production labor employed in all industries. Figure 7 shows clearly, however, that, in reality, this ratio was rising in nearly all industries.

One possible explanation for this relative employment shift is that technological change was "biased" toward the use of nonproduction labor ${ }^{64}$ Indeed, Berman, Bound, and Griliches conclude that technological change that saves production labor is the most likely explanation for the shift in demand toward nonproduction workers. They support this conclusion with strong correlations between skill upgrading within industries and increased spending by firms on computers and research and development ${ }^{65}$ Kreuger corroborates the importance of biased technological progress with his estimate that from one- to two-thirds of the 1984-89 increase in the premium on education was related to the use of computers. ${ }^{66}$ Bartel and Lichtenberg find that industries that use young technologies pay a premium wage. ${ }^{67}$

\section{Qualifications}

We have been able to reject the simplest theories asserting that international trade has placed downward pressure on the relative wages of unskilled labor. Because the United States tends to import unskilledlabor-intensive products, the problem with these explanations is that they imply an improvement in the U.S. terms of trade. As we have demonstrated, however, the terms of trade were basically flat in the 1980s (and actually declined in the 1970s).

\section{Complete Specialization}

There are theories that break the tight relationship between the terms of trade and relative factor prices by assuming complete specialization.

64. In the framework presented earlier, biased technological progress can be represented by allowing $F^{j}(\cdot)$ to vary over time.

65. Berman, Bound, and Griliches (1993).

66. Kreuger (1993).

67. Bartel and Lichtenberg (1991). It is unclear whether these workers justify their higher wages. Berndt and Morrison (1992), however, find a negative association between use of high-technology equipment and total factor productivity, although they also note that increases in high-tech equipment are labor using. 
These theories have the intriguing implication that unskilled workers in the United States are facing difficulties because there are too few of the poorest countries, rather than too many. One version of the argument stresses the impact of international capital flows; another, the international diffusion of technology. ${ }^{68}$ In both versions wage rates in the rich country fall at the same time that its terms of trade decline.

In the version that emphasizes capital mobility, there are three types of goods, differentiated by capital intensity. Only the rich country produces the most capital-intensive product (computers), and only the poor country produces the least capital-intensive product (textiles). Both countries produce the mid-range product (radios). Initially, the wage-rental ratio is higher in the rich than in the poor country. As capital shifts into the poor country, it increases its production of radios. This process not only shifts the poor country away from the production of textiles and toward radios, but also shifts the rich country away from the production of radios and toward computers. Within the rich country, therefore, the Stolper-Samuelson mechanism operates by releasing more labor than capital from the shrinking radio industry. This requires a lower wage-rental ratio to restore full employment. In the poor country an analogous effect operates to raise the wage-rental ratio. When the countries have sufficiently similar relative factor endowments, relative factor prices converge. This model has been presented using capital and labor; however, it could readily be presented using skilled and unskilled labor.

Three-good models with technological diffusion can generate a similar result. Consider technological change in a simple Ricardian model. The world is divided into pairs of lead and follower countries. ${ }^{69}$ The lead country initially specializes in the two more technologically sophisticated products (computers and radios), while the follower country specializes in the least (textiles). With technological advance in radios in the follower country, production of radios shifts from the lead to the follower nation. Again, this process shifts the rich country away from the production of radios and toward computers. It also shifts the poor country away from the production of textiles and toward radios. The result is an increase in the relative price of textiles. Real wages in the

68. Leamer (1992) presents the first version. Collins (1985), Johnson and Stafford (1993), and Krugman (1979) present varieties of the second version.

69. In Collins (1985) the argument involves three countries. 
lead country fall because the decline in the relative price of nowimported radios is offset by the increase in the relative price of textiles. From the standpoint of the lead country, the problem is too little production of textiles and too much production of radios.

Integrating the effects of labor force growth, technological diffusion, and capital mobility in a single model requires considerable fortitude. This has been done by Dollar in a model with complete specialization. ${ }^{70}$ Dollar shows that in the short run, labor-force growth in the South raises the terms of trade and the level of wages in the North. This rise in Northern wages, however, increases the rate of diffusion of both technology and capital to the South. This long-run effect, as we have seen, tends to worsen the North's terms of trade and equalize wages between the two regions.

Do these theories provide a better explanation of U.S. developments in the 1980s? Our findings in the previous sections suggest that they do not. First, in the two-factor models with capital and labor, we expected to see the terms of trade declining, the wage-rental rate falling, and product wages falling behind average productivity growth. We found, in fact, unchanged terms of trade, no decline in the wage-rental ratio, and product wages that matched productivity. Similarly, a two-factor model with nonproduction and production workers did not predict what we actually found: constant terms of trade, the relatively similar performance of import prices using production and nonproduction worker shares as weights, and the widespread shift toward the use of nonproduction workers. Therefore, we reject these models because they did not predict the facts of the 1980s that we actually saw.

\section{Union Wage Premiums}

So far, we have assumed that competition is perfect in the labor market. There is considerable evidence, however, that wages reflect rents due to unions and other factors. ${ }^{71}$ One hypothesis is that trade has had a particularly adverse effect on the wages of production workers in unionized manufacturing industries. This effect could operate either by reducing the number of unionized jobs that are available or by reducing the premium earned by unionized workers. Bound and Johnson find

70. Dollar (1986).

71. See, for example, Katz and Summers (1991). 
that changes in the share of unionization explain just 0.013 of the 0.163 rise in the premium earned by male college graduates over high school graduates in the 1980s. Blackburn, Bloom, and Freeman find that declines in the share of less educated workers employed in sectors with substantial rents can explain only between 10 and 25 percent of the increase in skill differentials for males. ${ }^{72} \mathrm{We}$ find that the premiums paid to unionized workers in manufacturing have not declined. The Employment Cost Index reports that between 1979 and 1989, the nominal compensation growth of nonunionized manufacturing production workers exceeded that of unionized manufacturing production workers by only 2.31 percent. This small difference is inconsistent with international competition's having squeezed union wages in traded-goods sectors in the 1980s.

\section{Nontraded Goods}

The divergence of productivity growth between manufacturing and nonmanufacturing may have played an important role in the wagedispersion story. Between 1960 and 1980 the share of goods in real spending remained roughly constant (43.5 percent in 1960 versus 44.4 percent in 1980), while the share of goods in nominal spending declined (from 49.5 percent to 45.2 percent). These two facts imply that the price of goods relative to services was falling. In addition, the long-run income elasticity of demand for goods is less than unity. Falling relative prices for goods, however, have induced a shift in spending toward goods that is large enough to offset the tendency for the share of goods in real spending to decline. The price elasticity of aggregate goods demand is also less than unity. Consequently, the share of goods in nominal spending has declined secularly.

These effects appear to have operated more powerfully between 1979 and 1989 because of the slowdown in the productivity growth of services. The shift toward spending on goods is in fact a response to the increased disparity between productivity growth in manufacturing and productivity growth in services. Although the decline in relative prices of goods is difficult to quantify precisely, a variety of measures indicate that it was unusually large in the 1980s. In the 1960s and 1970s, for example, the GNP deflator for goods declined relative to the overall

72. Bound and Johnson (1992); Blackburn, Bloom, and Freeman (1990). 
GNP deflator by 5.0 percent and 5.7 percent, respectively. In the $1980 \mathrm{~s}$ this decline increased to 13.1 percent. Similarly, the commodity price component of the CPI declined relative to the services component by 16.2 percent and 13.3 percent in the 1960s and 1970s, respectively, but by 23.9 percent in the 1980 s. And while the purchasing power index for finished goods fell by 5.3 percent in the 1960s and actually rose relative to the GNP deflator in the 1970 s, it fell by 10.9 percent in the 1980s.

If the overall demand for goods is inelastic, an increase in productivity growth that is passed through to final demand will, on balance, reduce the demand for factors of production used to produce goods. Although the share of nonproduction workers has been rising in manufacturing, the ratio of production workers to employment in manufacturing was almost twice as high as the ratio in the overall economy61 percent to 33 percent. Accordingly, the divergence in overall productivity growth could be a factor in reducing the relative wages of production workers. In this case, one mechanism for increasing employment opportunities for production workers would be an improvement in nonmanufacturing productivity.

\section{Conclusions}

We have examined the pressures that stem from trade by emphasizing price rather than quantity behavior. We have found that trade has not been the major contributor to the performance of U.S. average and relative wages in the $1980 \mathrm{~s}$. The constancy of the U.S. terms of trade during the decade casts doubt on the argument that technological diffusion has robbed U.S. workers of their rents associated with technological leadership. Similarly, our finding that workers have, on average, been compensated for their product wages casts doubt on those who invoke a Stolper-Samuelson process as the source of poor average wage performance. In addition, we doubt that a Stolper-Samuelson mechanism has played an important role in placing pressure on production worker wages. Indeed, both import and export prices indicate that the relative price of production-labor-intensive products actually increased slightly during the decade. Both the traditional two-good and the more sophisticated three-good models with complete specialization forecast 
that the relative decline in the wage of U.S. production workers will be associated with an increase in the ratio of production to nonproduction labor. We have found, however, a pervasive shift in U.S. manufacturing toward the increased use of nonproduction labor despite the rise in its relative wage.

This shift suggests that technological change has been the more important pressure on wages for production workers. Total factor productivity growth has been higher in manufacturing industries, which use nonproduction workers relatively intensively. Such a TFP change also implies an increase in the ratio of production to nonproduction labor, however. This means that in addition to TFP growth, technological progress was probably biased toward nonproduction labor. Finally, those who focus on real wage behavior without paying attention to productivity growth outside of manufacturing are writing Hamlet without the Prince. The major source of real wage convergence between the United States and other major industrial economies besides the United Kingdom lies in the disparate performance of services productivity. In addition, an important pressure on the relative wages of production workers may have been slow productivity growth in services.

\section{Appendix: Identifying the Skill Level of Workers}

Identifying the skill level of workers is always a problem in empirical work. A worker's skill level probably grows with some combination of education, on-the-job training, and work experience. Pinpointing a worker's skill level clearly requires a broad range of data, which, unfortunately, most data sets do not contain. The Annual Survey of Manufactures (ASM), for example, distinguishes nonproduction from production workers, but it does not track employees' education or work experience. Faced with these limited data, economists usually make skill distinctions more crudely. Two of the most common methods make occupational distinctions. The Current Population Survey (CPS) distinguishes white-collar from blue-collar labor, and the ASM distinguishes nonproduction from production labor. In each case, the former group usually is called "skilled" and the latter group "unskilled."

The obvious concern with these occupational distinctions is that they misclassify too many workers. Consider these two workers: an experi- 
enced machine-tool technician with a bachelor's degree in computer science who programs the computers driving these tools, and a recent high school dropout who files reports and runs mail. If they both work for a manufacturing firm, the nonproduction-production distinction will classify the technician as unskilled and the office runner as skilled. Clearly, this seems wrong. The worry is that such misclassifications are the rule rather than the exception, that is, that using either nonproduction-production or white-collar-blue-collar to categorize skill levels misplaces an unacceptably high number of people.

Berman, Bound, and Griliches convincingly argue, however, that these methods probably classify the majority of people correctly. Berman and his colleagues compare the nonproduction-production distinction, the blue-collar-white collar distinction, and the more-educatedless-educated distinction. Insofar as education is arguably the single most important determinant of one's skill level, it is reasonable to assume that the education distinction is the most reliable one. The question then becomes how closely do occupational distinctions match the education one. Berman, Bound, and Griliches conclude "that the relationship . . . is quite tight." 73 The conclusion is based on data they assembled on the educational attainment by broad occupational groups for 1973, 1979, and 1987. The data show that nonproduction and whitecollar workers consistently have more years of education than production and blue-collar workers. This holds true even for clerical nonproduction workers. It seems clear, then, that occupational distinctions do provide a reasonable separation between the more skilled and the less skilled.

Our work on relative wages uses ASM data. In light of this discussion, we feel comfortable considering nonproduction workers to be more skilled than production workers.

73. Berman, Bound, and Griliches (1993). 


\section{Comments \\ and Discussion}

Comment by Robert E. Hall. Lawrence and Slaughter have taken on a controversial and interesting topic. Their approach is uniformly reasonable and successful. They bring a strong dose of serious economic analysis to a subject that badly needs it.

The puzzles about wages in the United States that motivate the paper are, first, the low growth in the overall purchasing power of earnings during the past two decades and, second, the widening gap between the wages of highly educated and less educated workers. The point of the paper is that rising worldwide competition is not a contributor to these trends.

The authors start their investigation of the true culprits from the observation that product wage growth in manufacturing-the sector most affected by international trade-has not slowed down at all. U.S. manufacturing workers can buy a much larger quantity of manufactured goods with their earnings now than they could ten or twenty years ago. The factors explaining the stagnation of the overall purchasing power of earnings are rising prices in housing and in certain other parts of the nonmanufacturing economy, notably mining and utilities.

In addition to the disappointing performance of the prices of nonmanufacturing consumer goods, the authors note that declining prices of investment goods are another important factor in explaining the gap between the growing command of earnings over manufactured goods and the stagnated command over consumption goods. I find their discussion incomplete. Investment goods are intermediate goods. It is true that they are not consumed directly by households, but their services are inputs to the production of consumer goods. Presumably, the au- 
thors would not single out a pure intermediate product such as steel for the same treatment-they would not claim the declining relative price of steel as a reason for differences between trends in product wages and real wages.

The main purpose of the paper is to consider evidence on what I will call the Perot Hypothesis: increasing competition in world markets for products made by less-skilled workers is lowering U.S. welfare. The authors make the powerful point that the welfare effects on the United States of changes in world markets are measured by changes in U.S. terms of trade. When increased world competition lowers the relative price of a class of products, the United States suffers if it is a net exporter of that type of product and gains if a net importer. In fact, the United States is a net importer of low-skill-intensive products. The average American should gain if the Perot Hypothesis is correct. And the aggregate terms of trade for the United States have improved, as the paper's figures 2 and 3 show.*

The paper takes a closer look at the Perot Hypothesis within manufacturing. It shows directly that the relative prices of skill-intensive goods have fallen, not risen as the hypothesis would require. Increasing global competition has not dumped larger volumes of products made by low-wage, less-skilled workers onto the world market. On the contrary, the relative price effect has gone in the other direction. I find this a fully convincing refutation of the Perot Hypothesis.

The paper also investigates what would happen to skill intensity if the relative prices of skill-intensive goods rose, that is, if the Perot Hypothesis were true instead of false. Absent changes in the supplies of high- and low-skill workers, there would be an increase in the relative wages of skilled workers. Every industry would lower its skill intensity. Shifts in the composition of employment toward high-skill industries would keep the overall composition of employment constant.

I am puzzled by the authors' approach to testing the employment implications of the Perot Hypothesis. They find that skill intensity rose in most industries. But that finding tells us nothing, given the big positive change in the skill composition of the labor force. The authors wrote, "all we can conclude from examining the relative employment

*There are important pitfalls to measuring the terms of trade, including the fact that a significant fraction of imports and exports are not arm's length sales, but rather movements within the same firms. See Rangan and Lawrence (forthcoming). 
ratios is that the Stolper-Samuelson effect was dominated by some larger effect. . . . We cannot yet say anything about the absolute size of the Stolper-Samuelson effect. Perhaps it was large; perhaps it was nonexistent." The larger effect is the trend toward a more skilled labor force. It seems to me that they could look at the skill intensity of each industry relative to the overall average. There would be support for the Perot Hypothesis if the skill intensity of most industries fell relative to the national average.

Having disposed of the Perot Hypothesis, the authors turn to the explanation stressed by their predecessors, biased technical change. They consider Hicks-neutral change that is biased across industries-faster in the more skill-intensive industries. With respect to employment intensity, this hypothesis has the same implication as the Perot Hypothesis: declining skill intensity in every industry, made up by composition shifts toward skill-intensive industries. The same evidence that cast doubt on the Perot Hypothesis also casts doubt on the hypothesis of industry bias.

Figures $10 \mathrm{~A}$ and $10 \mathrm{~B}$ provide a direct check on industry bias of technical change. They show no correlation between growth of total factor productivity and skill intensity. But the authors argue that some kind of invisible correlation is lurking in the data. Their evidence is that average productivity growth is greater if industries are weighted by shares of skilled labor than if they are weighted by unskilled shares. To be convincing, the authors should develop a more direct measure of the correlation and explain why it is not apparent in the raw data.

The paper contains only a single short paragraph on the hypothesis on changes in relative wages in the 1980s that has received the most attention from economists, the factor bias in technical change. Several authors have concluded that only technical change that makes skilled workers more productive and unskilled ones less productive can rationalize the complete set of changes that occurred in the labor market in the 1980s. Further consideration of factor bias seems a top priority in this line of research.

I have a general misgiving about the use of the production-nonproduction distinction to capture differences in skills. Many nonproduction workers are clerical workers, janitors, security guards, and the like, not in the elite of the labor force. Many production workers have significant problem-solving roles; only a tiny fraction have routine assembly-line 
jobs. Data are certainly available by industry and occupation to study the issues of this paper in more detail.

I like the relentless application of simple general equilibrium concepts in this paper and the related emphasis on what can be learned from prices as well as from employment and wages. The bottom line is that worldwide competition is not the source of the poor growth of real earnings among American workers, nor is it the source of the painful decline in the real earnings of workers with less education and skills. Rather, the overall poor performance of real earnings is the result of skyrocketing housing costs and poor productivity growth in utilities and mining. These are sectors that have been particularly influenced by regulatory change over the past two decades. With respect to the growing dispersion in earnings, we are left with the hypothesis that there has been a sharp shift in technology favoring people with advanced general skills-Robert Reich's "symbolic analysts." It is a fascinating question, yet unanswered, why this shift began so sharply twenty years ago, when modernization previously had been a boon to the worker with lower skills.

Comment by Steven J. Davis and Robert $\mathrm{H}$. Topel: Anemic real wage growth and sharp, sustained increases in wage inequality are two of the most distressing aspects of U.S. economic performance during the past twenty years. These wage developments coincided with strong international trade growth, dramatic swings in the real exchange rate value of the dollar and the U.S. trade balance, an upsurge in foreign direct investment on U.S. soil, and a remarkable internationalization of economic activity in many capital markets. In the eyes of many, this coincidental timing points to growing globalization of the economy as the major culprit in America's poor real wage performance and increased earnings inequality. This perception about the recent past effects of globalization underlies much of the popular antipathy toward the North American Free Trade Agreement and other policy decisions that are seen as promoting further globalization.

With these facts and perceptions as backdrop, Robert Lawrence and Matthew Slaughter undertake a direct, frontal assault on the view that globalization-especially, international trade growth-has been the main driving force behind slow real wage growth and rising wage inequality in the United States. In the course of executing this assault, 
they effectively debunk the view that international trade developments explain the slow growth in average real wages since 1973. They also build a case against the view that international trade developments contributed to increased wage inequality. In this regard we find their analysis less persuasive. Although we concur with their conclusion that emphasizes the role of technical change favoring more skilled workers, we think the role of international trade developments in recent U.S. relative wage behavior remains an open question.

\section{Average Real Wage Performance}

Lawrence and Slaughter deftly guide readers through a sequence of calculations that shed light on the phenomenon of slow real wage growth. They first show that a common measure of wage performancethe average real hourly wage of production workers-greatly understates the growth of overall worker compensation. Based on the consumer price index for urban households (CPI-U), real hourly wages of production workers fell by 11 percent from 1979 to 1991 , whereas real hourly compensation in the business sector grew by 1.5 percent. The latter measure covers nonproduction workers and self-employed persons, and it encompasses fringe benefits in addition to wages and salaries. More rapid wage growth for nonproduction workers and more rapid growth of nonwage compensation each account for about one-half of the discrepancy between these two measures of real wage performance.

Between 1973 and 1979 average real hourly compensation increased in line with output per worker in the U.S. business sector. Hence, the blame for slow real wage growth during this interval rests squarely with the slow growth of labor productivity. Although greater globalization could in theory cause a sharp increase in capital's share of income in a capital-rich country such as the United States, Lawrence and Slaughter show that no such development transpired in practice.

Labor productivity continued to grow slowly after 1979, but real compensation grew even more slowly. From 1979 to 1991 output per worker in the business sector rose by 10.5 percent, whereas real hourly compensation (using the CPI-U) rose by a mere 1.5 percent. Lawrence and Slaughter show that this "output-wage gap" reflects a divergence between the consumption wage and the product wage after 1979. Two 
factors account, in roughly equal measure, for this divergence: an increase in the relative price of housing, which workers consume but do not produce; and a decline in the relative price of business investment goods, which workers produce but do not consume. Once again, changes in labor's share of income played no important role in the slow growth of average real compensation during this period. Nor does an adverse movement in the terms of trade (over the period as a whole) help account for the relatively slow growth in the consumption wage.

Thus, Lawrence and Slaughter's calculations lead to three important conclusions. First, average real wages grew slowly during the past twenty years, because labor productivity grew slowly. In this respect, a deeper explanation for slow real wage growth awaits an explanation for the slowdown in productivity growth. Second, after 1979 two other important factors in the slow growth of the consumption wage were the rising relative price of the housing stock and the falling relative price of business investment goods. As Bob Hall has observed, the main puzzle here involves the apparent failure of price declines for business investment goods to work their way through the chain of production to (measured) price declines for consumer goods. Third, international trade played no important role in the slow growth of real wages through either a terms of trade effect or an effect on labor's share of income.

\section{Relative Wage Performance and the Stolper-Samuelson Mechanism}

Turning to explanations for relative wage movements, Lawrence and Slaughter develop two main pieces of empirical evidence. One piece involves changes in the relative wages and quantities of skilled labor in the U.S. manufacturing sector. The second piece of evidence involves changes in the relative prices of products that differ with respect to labor skill intensity. Both types of evidence speak to the empirical implications of the Stolper-Samuelson mechanism by which international trade influences domestic factor intensities and relative factor prices.

According to Stolper-Samuelson, international trade affects relative wages through its impact on relative product prices. Because unskilled labor is relatively abundant in the rest of the world, greater international openness drives down the relative U.S. price of traded goods that intensively utilize unskilled labor in production. This relative price effect 
brings about a contraction of traded goods sectors that intensively utilize unskilled labor and an expansion of traded goods sectors that intensively utilize skilled labor. The sectoral reallocation of production activity drives down the relative demand for and relative wage of unskilled workers in the U.S. economy. Consequently, all sectors shift factor intensities toward unskilled labor.

In confronting these theoretical implications with the data, Lawrence and Slaughter interpret nonproduction and production workers as skilled and unskilled labor, respectively. According to their data, the ratio of annual wages for nonproduction workers to annual wages for production workers in the U.S. manufacturing sector rose by 10 percent between 1979 and 1989. During the same period the ratio of nonproduction to production worker employment rose from 0.35 to 0.44 . Qualitatively similar patterns of relative wage and quantity movements occurred within most manufacturing industries between 1979 and 1989.

Because an explanation for a rising skill premium à la StolperSamuelson requires a shift away from nonproduction workers within sectors, these facts reject the most straightforward trade-based interpretation of increased wage inequality. As Lawrence and Slaughter emphasize, an explanation for a rising skill premium based on Hicksneutral technical change at the sectoral level also implies a shift away from nonproduction workers within sectors. Thus, neither international trade nor Hicks-neutral technical change appears to be the dominant driving force behind increased wage inequality. Instead, the simultaneous increase in the relative wages and quantities of more skilled workers indicates that technical change has been skill-biased in the sense of inducing more intensive use of skilled labor at any given relative wage.

\section{The Role of Skill-Biased Technical Change}

By this route Lawrence and Slaughter arrive at the conclusion that skill-biased technical change within sectors was a key driving force behind the growth in wage inequality. Several other researchers have arrived at the same conclusion, and in most cases by essentially the same route. Berman, Bound, and Griliches provide evidence that foreign outsourcing cannot account for the pronounced shift away from production workers, thereby reinforcing the skill-biased technical 
change interpretation of the relative wage and quantity evidence. ${ }^{1}$ Davis and Haltiwanger show that the shift toward nonproduction workers occurred disproportionately at larger plants during the period 1977 to $1986 .^{2}$ They also document the pronounced upgrading of manufacturing workers' educational and occupational skill intensity since the late 1960s. Krueger argues that dramatic declines in the price of computing power and the consequent spread of personal computers in the workplace shifted the production function in ways that favor more skilled workers. ${ }^{3}$

The argument for the skill-biased technical change hypothesis is a bit like inferring the existence of Pluto, because Neptune's orbit does not otherwise fit the predictions of theory. Surely, the hypothesis of Pluto's existence became more compelling when Pluto was actually sighted in a telescope. Likewise, explanations for a rising skill premium that stress skill-biased technical change will become more compelling when we observe Pluto's counterparts on our computer screens. In Lawrence and Slaughter's analysis, and in much other work on relative wage behavior, skill-biased technical change is largely a name for our ignorance. Economists need a great deal more research in the same spirit as Krueger's study of the role of computers-research designed to find Pluto.

Another problem with the skill-biased technical change hypothesis becomes evident when the nonmanufacturing sector is examined. To appreciate the problem, consider the most widely used measure of skill intensity: years of schooling. Although we have not examined the data, we are confident that average years of schooling rose across a broad range of nonmanufacturing industries during the 1979-91 period. Of course, we also know that the education premium rose sharply during this period. Hence, to fit the relative wage and quantity facts in the nonmanufacturing sector, we are again driven to the hypothesis of skillbiased technical change. But, as Lawrence and Slaughter stress, output per hour in the nonmanufacturing sector grew by a mere 4.5 percent between 1979 and 1991. This meager growth in labor productivity does not fit comfortably with an explanation for relative wage developments that postulates an important role for skill-biased technical change. We

1. Berman, Bound, and Griliches (1993).

2. Davis and Haltiwanger (1991).

3. Krueger (1993). 
are left with a conundrum: If skill-biased technical change has been important, why has labor productivity growth been so slow? We can offer no answer, but posing the question heightens our suspicions about the data. Either productivity growth or changes in the skill intensity of workers are not being measured correctly.

Stolper-Samuelson Again: Should Prices or Quantities Be Used to Gauge Trade Effects?

Well-known studies by Borjas, Freeman, and Katz and Katz and Murphy use the factor content of international trade to draw inferences about the impact of trade flows on relative wages. ${ }^{4}$ Because the embodied labor skill content differs among goods, changing trade flows potentially alter effective relative labor supplies. The United States tends to import goods that embody a high intensity of unskilled labor and to export more skill-intensive goods. Consequently, a growth in balanced trade or an expansion of the trade deficit increases the implicit relative supply of unskilled labor. By measuring these implicit relative supply shifts and specifying an aggregate production function, Borjas, Freeman, and Katz and Katz and Murphy estimate the contribution of changing trade flows to U.S. relative wage movements. The largest estimated effects are associated with the sharp expansion in the U.S. trade deficit during the early 1980s. Borjas, Freeman, and Katz estimate that growth in the trade deficit accounted for 15 to 25 percent of the rise in the college-high school wage differential between 1980 and 1985 .

Lawrence and Slaughter develop a trade theorist's critique of this "quantity" approach to gauging the impact of trade on relative wages. ${ }^{5}$ At the heart of this critique lies the Stolper-Samuelson theorem. The theorem says that "relative [product] price changes are the critical intervening variable in the chain of causation from trade to factor prices." Thus, the theorem directs the empirical researcher to examine the terms of trade rather than trade flows in gauging the impact of trade on relative wages. Further, Lawrence and Slaughter clearly explain how the implicit relative supply shifts embodied in changing trade flows can lead to incorrect inferences regarding trade's impact on relative wages. After examining the pattern of product price changes for traded man-

4. Borjas, Freeman, and Katz (1992); Katz and Murphy (1992).

5. See Bhagwati (1991); and Deardorff and Hakura (1993) for similar critiques. 
ufacturing goods, Lawrence and Slaughter conclude that "the StolperSamuelson process did not have much influence on America's relative wages in the 1980s. In fact, because the relative price of nonproductionlabor-intensive products fell slightly, the Stolper-Samuelson process actually nudged relative wages toward greater equality.' In our view, this conclusion is premature. Several considerations argue in favor of a more tentative assessment of the evidence developed by the authors.

One important consideration involves the role of technical change. Once technical change (whether Hicks-neutral or skill-biased) is accepted as a major driving force behind relative wage movements, relative price movements for traded goods no longer provide an accurate indicator of the direction or magnitude of trade's effects on relative wages. Technical change that favors skilled workers could easily mask Stolper-Samuelson effects that raise the skill premium. Suppose, for example, that relative wage movements reflect declining barriers to international trade and relatively rapid productivity growth in skillintensive export sectors. Suppose, also, that the demand elasticity for skill-intensive goods is greater than one and less than infinity. In this scenario, easier trade raises the relative price of skill-intensive export goods, whereas productivity growth lowers it. Both developments drive up the relative wage for skilled workers. According to this scenario, the productivity-induced decline in the price of export goods would cause Lawrence and Slaughter to attribute an unduly favorable effect of trade on wage inequality developments.

A related consideration arises in connection with scale economies. Some skill-intensive export sectors (such as software development) exhibit large fixed costs and small marginal costs of production. For these sectors globalization offers a wider scale of operations over which to spread fixed costs and generate revenues. Some part of these additional revenues are likely to accrue to skilled workers. Here, globalization can raise returns for skilled labor, even as it brings greater competition that drives down unit product prices. One suspects that globalization helps to enrich Microsoft employees, even thought it facilitates greater competition and lower software prices.

These remarks suggest that a focus on the terms of trade, as advocated by trade theorists, comes with its own pitfalls. Although we accept the Lawrence and Slaughter critique of the quantity approach adopted by labor economists, it is not apparent to us which of two 
imperfect approaches delivers more reliable inferences. Our hesitancy to accept the authors' conclusion about trade's relative wage effects is reinforced by two additional concerns. First, we would like to see the analysis recast in terms of better indicators of worker skill intensity, such as educational attainment or a more detailed occupational breakdown. We are quite prepared to believe that nonproduction workers are typically more skilled than production workers, but the relative skill levels of these two categories probably varies greatly across industries and perhaps over time. Second, we would like to see the analysis extended beyond the manufacturing sector. Much recent growth in international trade occured in skill-intensive sectors that export services. It seems likely that this component of trade growth has contributed to rising real and relative wages for highly skilled workers.

In conclusion, we think the link between international trade and relative wage behavior remains an open issue. Neither the focus on trade flows adopted by labor economists nor the focus on the terms of trade advocated by trade economists has yet settled the issue.

General Discussion: Several participants expressed reservations about the paper's finding that imports have, by and large, not been responsible for the widening gap between the wages of higher- and lower-skilled workers in the United States. Those disagreeing with the authors' results suggested that their treatment of technological change in the U.S. economy as exogenous may be hiding the effects of trade on wages. Paul Romer, John Helliwell, and Martin Baily all argued that technological change cannot be considered exogenous because some portion of apparent technological change in the United States is driven by the globalization of production, as low-skilled, labor-intensive manufacturing tasks gradually move from the United States to low-wage countries, such as Mexico, while the most skill-intensive jobs continue to be performed in the United States. This globalization of production, therefore, reduces the relative demand for unskilled workers in the United States and thus lowers their wages relative to skilled workers.

Timothy Bresnahan, however, suggested that determining the endogeneity or exogeneity of technological change is unimportant because the most important factor behind this change is the computerization of work, particularly white-collar work, which is occurring in the larger eco.lomy and is not directly connected with trade. Whether computer- 
ization has actually increased productivity is irrelevant, Bresnahan said, because it has shifted the demand for labor toward those with computer skills, thereby raising the relative wages of certain classes of skilled workers.

Robert Gordon also was not convinced that the paper shows that imports have had minimal effects on wages in the United States. He argued that looking at terms of trade for relative prices cannot shed light on the marginal effects of opening up a closed economy to trade. If those effects are to be assessed, one should look at the factor markets as well as the product markets, he said, noting that immigration has reduced the relative wages of low-skilled workers in states receiving large numbers of immigrants.

Several participants commented on methodological and measurement issues. Gordon argued against using the CPI to compute real wages during the 1977-83 period, because at that time mortgage interest rates were causing an upward bias in that index. He suggested using a chainweighted personal consumption deflator.

Commenting on work he had co-authored on the extent to which industry structure is related to effect of trade on wages, Henry Ergas said that for almost all of the eleven industrial countries he examined, increased import penetration had significant effects in reducing relative wages in a given industry when that industry was characterized by few economies of scale and little product differentiation. By contrast, he said, in industries characterized by significant economies of scale and extensive product differentiation, increased trade exposure actually increased relative wages. In the latter case, this phenomenon may be attributable to increased trade having a positive effect on productivity, which in turn results in increased worker compensation. He suggested that the authors look at the effects of industry structure and imperfect competition on the behavior of wages in the face of import competition.

Richard Gilbert suggested that expansion of product differentiation that widens the price gap between the highest- and lowest-quality products may affect the relative income of different classes of workers. Gilbert argued that if it can be assumed that people with higher incomes consume higher-quality goods, a widening price gap between the highest- and lowest-quality goods results in a more rapidly rising price index for higher earners than for low earners. In such a case, Gilbert argued, 
creating separate price indices for earners of different income levels would be necessary to determine their real relative wages.

Frank Lichtenberg noted that one of the major findings of the paper is that the apparent divergence of productivity growth and real wage growth is due to the divergence between the GDP deflator and the CPI. He wondered if the deflator-CPI divergence could persist over the long run. Citing computers as an example, he said that if their price falls, computers should become an increasing share of capital stock, which in turn should reduce the cost of capital and, eventually, should result in lower consumer prices. If it were true that the divergence could not persist, he argued, the CPI might be expected to grow more slowly than the GDP deflator in the future. 


\section{References}

Abowd, John M., and Richard B. Freeman, eds. 1991. Immigration, Trade, and the Labor Market. Chicago: University of Chicago Press.

$\rightarrow$ Baily, Martin Neil, and Robert J. Gordon. 1988. "The Productivity Slowdown, Measurement Issues, and the Explosion of Computer Power." Brookings Papers on Economic Activity 2:347-431.

$\rightarrow$ Bartel Ann P., and Frank R. Lichtenberg. 1991. "The Age of Technology and Its Impact on Employee Wages.' Economic Innovation and New Technology 1 (2): 215-31.

Berman, Eli, John Bound, and Zvi Griliches. 1993. "Changes in the Demand for Skilled Labor within U.S. Manufacturing Industries: Evidence from the Annual Survey of Manufacturing." Working Paper 4255. Cambridge, Mass.: National Bureau of Economic Research. January.

Berndt, Ernst R., and Catherine J. Morrison. 1992. High-Tech Capital Formation and Economic Performance in U.S. Manufacturing Industries: An Exploratory Analysis. Cambridge: Mass.: MIT Press.

Bhagwati, Jagdish. 1991. "Free Traders and Free Immigrationists: Strangers or Friends?" Working Paper 20. Russell Sage Foundation, New York. April.

Blackburn, Mckinley, David Bloom, and Richard Freeman. 1990. "The Declining Economic Position of Less Skilled American Males." In Burtless, Gary, ed. A Future of Lousy Jobs? Washington, D.C.: Brookings.

Borjas, George J., Richard Freeman, and Lawrence F. Katz. 1992. "On the Labor Market Effects of Immigration \& Trade." In Borjas, George J. and Richard Freeman, eds. Immigration and the Workforce. Chicago: University of Chicago Press.

$\rightarrow$ Bound, John, and George Johnson. 1992. "Changes in the Structure of Wages in the 1980s: An Evaluation of Alternative Explanations." American Economic Review 82 (June): 371-92.

$\rightarrow$ Bowen, H. P., E. Leamer, and L. Sveikauskas. 1987. “Multicountry, Multifactor Tests of the Factor Abundance Theory." American Economic Review 77 (December): 791-809.

Bureau of Labor Statistics, U.S. Department of Labor. 1991. "International Comparisons of Hourly Compensation Costs for Production Workers in Manufacturing, 1975-90." Report 817. Washington, D.C.

$\rightarrow$ Collins, Susan M. 1985. "Technical Progress in a Three-Country Ricardian Model with a Continuum of Goods." Journal of International Economics 19 (August): 171-79.

$\rightarrow$ Cutler, David, and Lawrence Katz. 1991. "Macroeconomic Performance and the Disadvantaged.' Brookings Papers on Economic Activity 2:1-74.

Davis, Steven J. 1992. "Cross-Country Patterns of Change in Relative 
Wages." In Blanchard, Olivier, and Stanley Fischer, eds. 1992 Macroeconomics Annual. New York: National Bureau of Economic Research.

Davis, Steven J., and John Haltiwanger. 1991. "Wage Dispersion between and within U.S. Manufacturing Plants, 1963-1986." Brookings Papers on Economic Activity: Microeconomics: 1991: 115-180.

Deardorff, Alan V., and Dalia Hakura. 1993. "Trade and Wages: What Are the Questions?" Paper delivered to a seminar on "The Influence of International Trade on Jobs and Wages." American Enterprise Institute, Washington, D.C. September.

$\rightarrow$ Deardorff, Alan, and Robert Staiger. 1988. "An Interpretation of the Factor Content of Trade." Journal of International Economics 24 (February): 93107.

$\rightarrow$ Dollar, David. 1986. “Technological Innovation, Capital Mobility, and the Product Cycle in North-South Trade." American Economic Review 76 (1, March): 177-90.

Ethier, William. 1984. "Higher Dimension Trade Theory." In Jones, R. W., and P. B. Kenen, eds. Handbook of International Economics. Amsterdam: North-Holland.

Freeman, Richard B., and Lawrence Katz. 1991. "Industrial Wage and Employment Determination in an Open Economy." In Abowd and Freeman (1991).

Freeman, Richard B., and Karen Needels. 1991. "Skill Differentials in Canada in an Era of Rising Labor Market Inequality.' Working Paper 3827. National Bureau of Economic Research, Cambridge, Mass. September.

Gullickson, William. 1992. "Multifactor Productivity in Manufacturing Industries." Monthly Labor Review 115 (October): 20-32.

Hicks, John. 1953. "An Inaugural Lecture: The Long-Run Dollar Problem.", Oxford Economic Papers. June.

Helpman, E., and K. Krugman. 1985. Market Structure and Foreign Trade. Cambridge, Mass.: MIT Press.

Johnson, George E., and Frank P. Stafford. 1993 " International Competition and Real Wages.' Paper presented at American Economic Association Annual Meeting, January 5-7, 1993.

$\rightarrow$ Katz, Lawrence F., and Kevin M. Murphy. 1992. "Changes in Relative Wages, 1963-1987: Supply and Demand Factors." Quarterly Journal of Economics 107 (February): 35-78.

$\rightarrow$ Katz, Lawrence F., and Lawrence H. Summers. 1989. "Industry Rents: Evidence and Implications." Brookings Papers on Economic Activity: Microeconomics: 1989: 209-290.

$\rightarrow$ Krueger, Alan B. 1993. "How Computers Have Changed the Wage Structure: Evidence from Microdata, 1984-1989.' Quarterly Journal of Economics 108 (February): 33-60. 
$\rightarrow$ Krugman, Paul. 1979. "A Model of Innovation, Technology Transfer, and the World Distribution of Income." Journal of Political Economy 87 (April): 253-66. Fall): 19-31.

Lawrence, Robert Z. 1984. Can America Compete? Washington, D.C.: Brookings.

$\longrightarrow \rightarrow$ 1990. "U.S. Current Account Adjustment: An Appraisal.' Brookings Papers on Economic Activity 2:343-92.

Leamer, Edward E. 1992. "Wage Effects of a U.S.-Mexican Free Trade Agreement."' Working Paper 3991. National Bureau of Economic Research, Cambridge, Mass.

McKinsey Global Institute. 1992. Service Sector Productivity. Washington, D.C.

Murphy, Kevin M. 1992. "Changes in Wage Structures in the 1980s: How Can We Explain Them?' University of Chicago. February. Mimeo.

Murphy, Kevin M., and Finis Welch. 1991. "The Role of International Trade in Wage Differentials." In Kosters, Marvin, ed. Workers and their Wages. Washington D.C.: American Enterprise Institute.

$\rightarrow \rightarrow$. 1992. "The Structure of Wages."' Quarterly Journal of Economics 107 (February): 285-326.

Rangan, Subramanian, and Robert Z. Lawrence. Forthcoming. "The Responses of U.S. Firms to Exchange Rate Fluctuations: Piercing the Corporate Veil."' Brookings Papers on Economic Activity 2.

$\rightarrow$ Revenga, Ana L. 1992. "Exporting Jobs? The Impact of Import Competition on Employment and Wages in U.S. Manufacturing." Quarterly Journal of Economics 107 (February): 255-82.

Reich, Robert B. 1991. The Work of Nations: Preparing Ourselves for 21st Century Capitalism. New York: Alfred A. Knopf.

$\rightarrow$ Stolper, Wolfgang, and Paul A. Samuelson. 1941. "Protection and Real Wages."' Review of Economic Studies (November): 58-73.

UNCTC (United Nations Center on Transnational Corporations). 1991. World Investment Report: 1991. New York: United Nations.

$\rightarrow$ Williamson, Jeffery. 1991. "Productivity and American Leadership: A Review Article." Journal of Economic Literature 29 (March): 51-68. 